\title{
GAME BIRDS OF NORTH AMERICA
}

\section{FRANK A BATES}



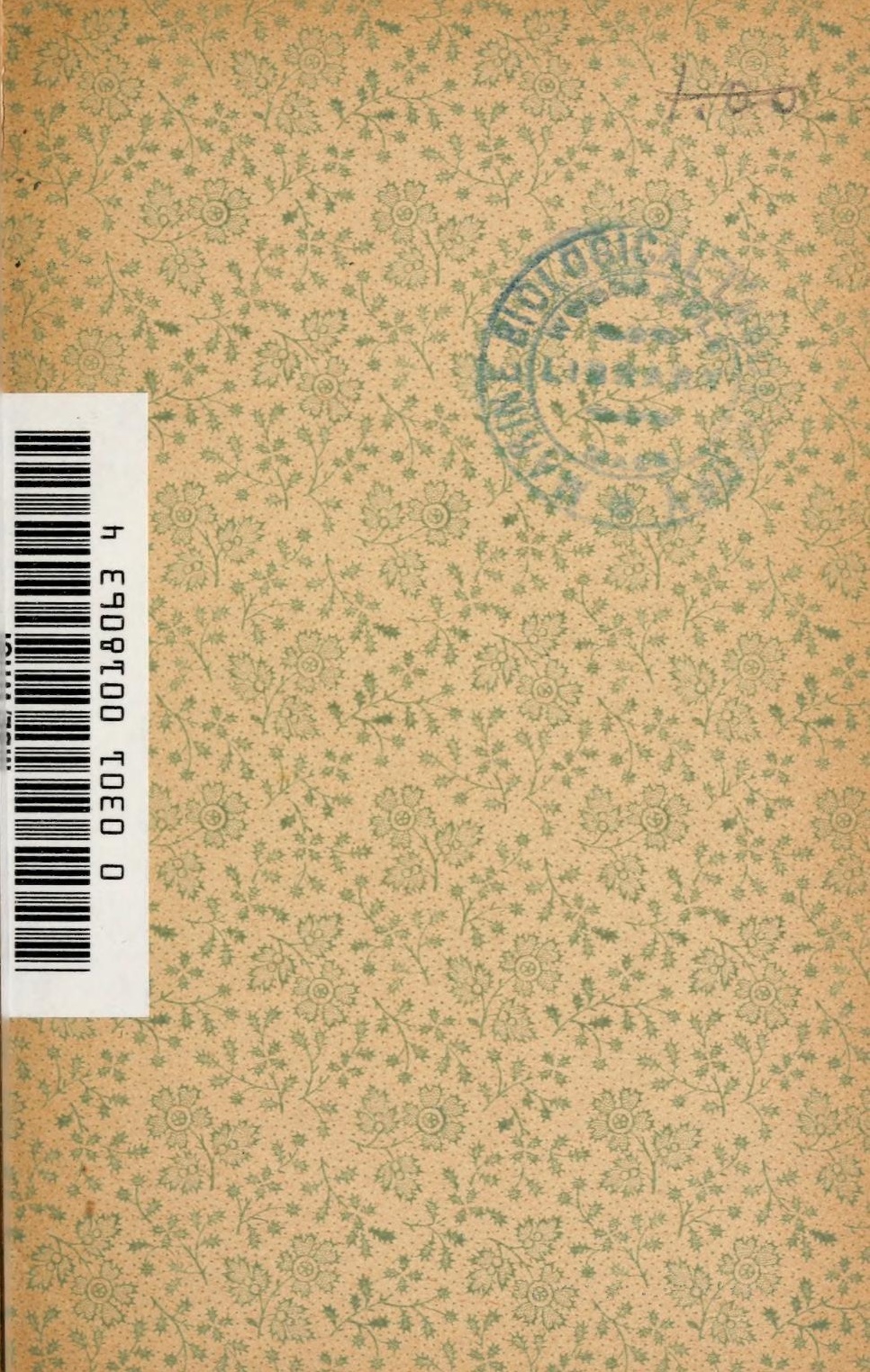





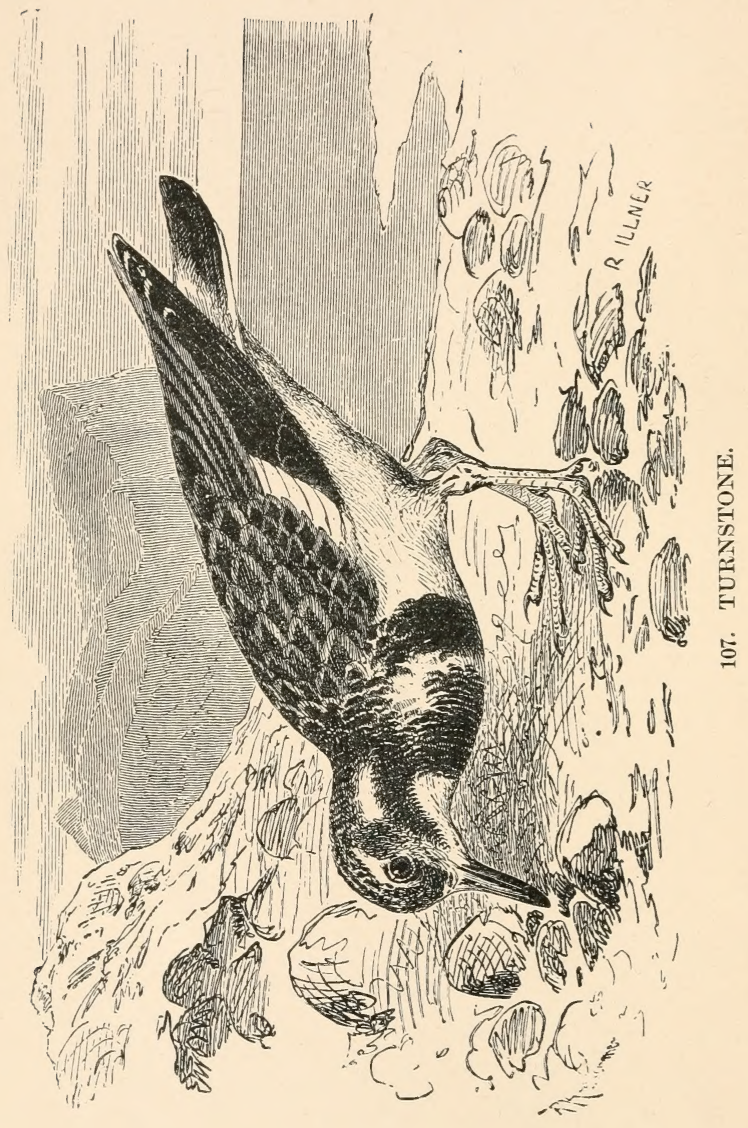




\title{
The Game Birds \\ OF NORTH AMERICA
}

A Descriptive Check-List

\author{
BY \\ FRANK A. BATES \\ President "Boston Scientific Society," and formerly \\ Associate Editor "Ornithologist and Oologist."
}

\section{IIlustratè}

\author{
BOSTON \\ BRADLEE WHIDDEN \\ I 896
}


Copyright, 1896, BY

BRADLEE WHIDDEN. 


\section{INTRODUCTORY.}

Ix considering the preparation of this list, the first point was - "What is a game bird?"

What gunner will armit that his favorite bird is not game, although it be tabooed by his neighbor? And here again another difficulty arose, for many a man shoots Meadow Larks and Reed-birds, and would scorn the imputation that he was not a sportsman, or that these birds were not game.

To aroid one horn of the dilemma without getting hooked by the other, I have manufactured this definition : A game bird is one which is suitable for food and which is habitually pursued by man for sport, demanding skill and dexterity for its capture. I take it for granted that every sportsman is a gentleman, and would not slaughter more game than he could find a use for, and that he would not descend to the level of the pot-hunter, who will kill Robins and other insectivorous birds simply because they are fit to eat.

With this explanation, I apologize beforehand to anyone whose corms I have trodden upon, offering as an excuse, my desire to afford a convenient reference list adapted to the sportsman's neerls without compelling him to wander among a mass of useless matter. I have also marked with a star (*) those birds which are not generally accepted as game, although it has been rery difficult to draw the line.

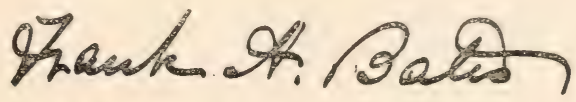




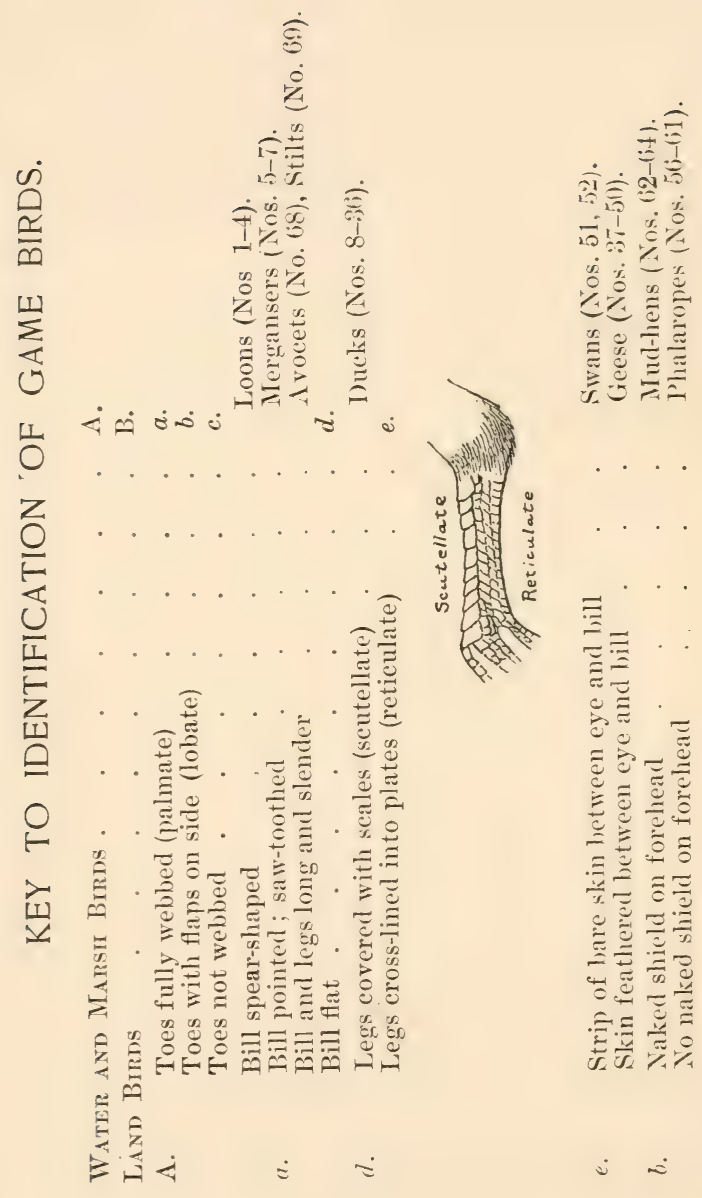


$-5 \stackrel{0}{0} \dot{0}$

I0 $1000 \%$

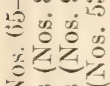

$\angle+\infty$ का

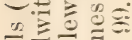

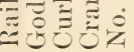
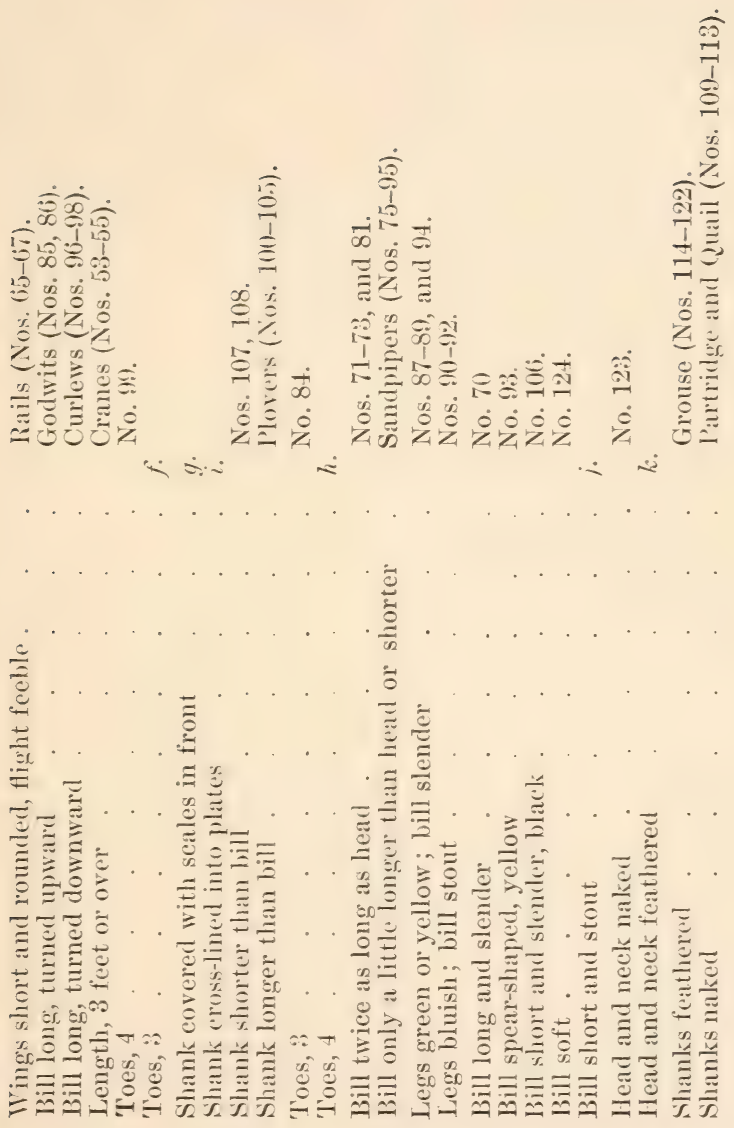

2633 



\section{WATER BIRDS.}

\section{1. * LOON. GREAT NORTIERN DITER. \\ Lrinator imber.}

Predominating color, a deep greenish-black in old birds, brownish-black in young, marked with small white spots. Breast and under parts white, and a patch of white lines on the throat. The old hirds have a band of white

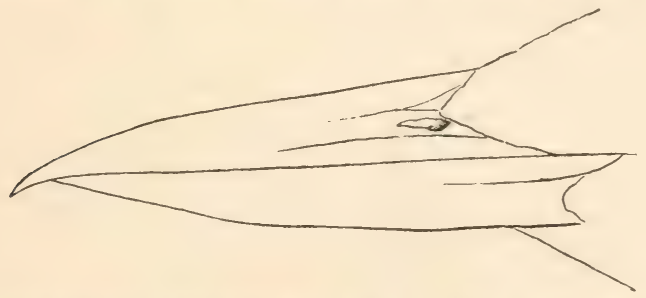

lines about the neck. Iris of old bird, reel; young, brown. Extent of wings about $t$ feet; length from tip of bill to tip of tail, about 3 feet. The largest one I ever heard of measured to inches in length and weighed $17 \frac{5}{8}$ lbs. Feet and bill l,lack, the latter straight and tapering. Leg's set far back on the body.

Habitat-Entire Northern Hemisphere; in winter goes as far south as the Gulf of 
Mexico. Common, in summer, in the large fresh-water ponds; earlier and later in the season in the bays and harbors. Exceedingly wary and difficult of approach, diving at the slightest suspicion of danger and with remarkable powers in this direction.

The flesh has a decidedly fishy taste, but "baked breast of loon" and "loon stew" are esteemed as delicacies by many.

Its congeners are

\section{2. * BLACK-TIIROATED LOON.}

Urinator arcticus.

General color like No. 1, but with less white on throat. Somewhat smaller, measuring $3 \frac{1}{3}$ feet in extent and $2 \frac{1}{2}$ feet in length.

Habitat - More northern than the loon.

\section{3. * PACIFIC LOON.}

Urinator pacificus.

Still smaller than No. 2 ; otherwise nearly the same. This bird measures only 2 feet in length.

Habitat - Pacific coast, Alaska to Gulf of California.

\section{4. * RED-THROATED LOON. \\ Urinator lumme.}

About the size of No. 3 and with the same general colors, but the sides of the head and 
throat are gray, with a patch of rich brownishred on the throat in the old bird, which is lacking, or nearly so, in the young birds, which, however, are easily recognized by the numerous white spots on the back.

Habitat - About the same as No. 1, but somewhat more confiner to the salt water.

\section{5. * AMERICAN MERGANSER.}

\section{GOOSANDER. POND SHELDRAKE.}

\section{Merganser americanus.}

Predominating color, black; under parts dirty yellowish-white. Head with a slight crest. Wing mostly white. Female of more subdued color's. Iris of ere carmine red in male, yellow in female. Feet generally yellow; bright red in the male in the spring.

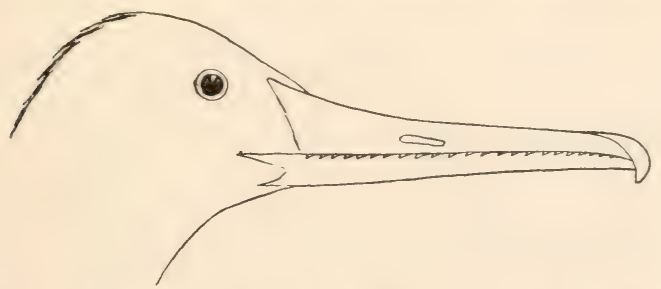

Bill red, saw-toothed on the mouth, with a pronounced hook on the end. Average length about 2 feet; extent nearly 3 feet. The female is much smaller than the male. 
Habitat- Entire North America. Breerls in the northern section; not nueommon anywhere in the ponds and large rivers during the various seasons, as it migrates south with the approach of cold weather. 'They are expert divers, feecling upon fish. Their flesh is rank, but will fill the belt cavity when nothing else presents itself.

\section{6. * RED-BREASTED MERGANSER. SAL'T-WATER SIIELIRAKE. SAWBILL. \\ Merganser serrator.}

Resembles No. 5, but has a white ring about the neck of the male, and the crest is more pronounced. The great feature of distinction is the brownish-red color which adorns the breast. The female is unlike the male, but is quite recognizable.

Habitat - Northern sections. Not so common in the United States as No. 5. 'They are principally confined to the seacoast, and their habits are much like the last named.

\section{7. *HOODED MERGANSER. Lophodytes cucullatus.}

Back of male black, under side white; a beautiful white crest, fronted and bordered with black, decorates the head. The female is a little smaller; brownish, with a much smaller crest, but with much more than No..6. 
Eyes yellow. A much smaller bird than the rest of the family, being only $1 \frac{1}{2}$ feet long, and a little over 2 feet in extent.

Ifabitat - North America in general, south to Cuha. This beautiful bird is generally regarded as a prize by gumners, as it is not particularly common anywhere, and the male bird attracts admiration by its graceful carriage and elegant plumage. It is an active diver, feeding unon small fish and aquatic insects, living principally upon the fresh water. Like its relatives, its flesh is but inferior food.

\section{MIALLARD. GREEN-HEAD. WILD DUCK.}

Anas boschas.

Breast of male in spring silver graty, with fine markings of dartier. Back black. Hearl

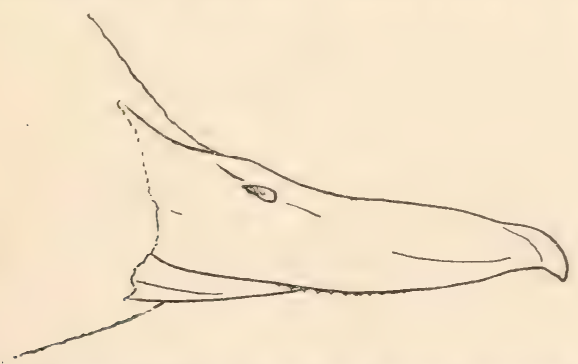

glossy green, with a white band around the neck. The wing bear's a beautiful green 
patch, framed in black and white. The female is dusky brown and mottled with darker. In the summer the drake loses his green head, but can be easily distinguished from the female by the wing patch and the upeurled tail. Eyes brown ; feet reddish; bill black, spotted with orange. Length 2 feet. Extent 3 feet,

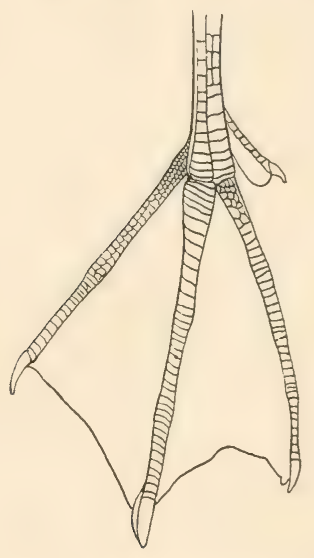

or a little less. Average weight of males 2 lbs. 9 oz., females a little less.

Habitat - The whole of the Northern Hemisphere. They are not at all common in New England, but are very plenty on the inland lakes and rivers, as they are essentially fresh-water birds.

This species is the progenital stock of om' domestic duck, and has no doulst often been mistaken for such by gunner's. 'They hybridize easily with the Black duck, and such 
bircls make excellent decoys for shooting from blinds. They are easily domesticated, and, wild or not, their flesh is of fine flavor and clean, as they are vegetable feeders.

\section{BLACK DUCK. DUSKY DUCK. Anas obscura.}

Predominating color, dark brown; lighter on the breast, head and neck. The edges of the feather's are shaded with dusky, giving the appearance of shell work or scallops. 'The wing patch is violet; the eyes are brown, the bill yellowish-brown; feet orange, with dark webs. About the same size as No. 8, averaging a little less in weight, and resembling the female of the mallaril to a great degree, differing in having no white marking's except on the inside of the wings. The male and female are much alike, but the latter is generally of a lighter shade.

Habitat - Eastern North America. This bird favor's the salt water more than the mallard, and will be found in immense flocks in our bays and harbors, although it drops into the large ponds during its migratory Hights, and is there shot from blinds by means of decoys. Our gumners on the New England coast will insist that there are two varieties, viz, the Redl-leg or Southern duck, and the Black-leg or Winter duck, although no lists to-day recognize a difference. My friend Leonard, of Marshfield, Mass., writes me as follows: "In my opinion they are different 
birds. 'The Red-leg is larger, tamer, and does not winter here with us. It leaves us here (lat. $42^{\circ} \mathrm{N}$.) about the micllle of November and does not appear again until the last of February, when they go north. The Blackleg is with us till next May and sometimes breeds here." The Rerl-leg weighs ncarly 3 1bs. The Black-leg about $2 \frac{1}{4} 1 \mathrm{lbs}$.

I shall not attempt to decide the question, for I lave no desire to add my name to the list of variety makers (there are too many already), but there is food for thought in the above, coming as it does from one of the best informed market gumners on the coast.

The Black duck is one of the finest talole birds, and always commands a call in the markets.

\section{FLORIDA DUCK.}

MOTTLED DUCK (VARIETY).

Anas fulvigula.

Resembles No. 9 very closely, but the cheeks, chin and throat are more inclined to a buff color, and the light-brown markings of that bird are replaced by the same color. There is a black spot at the base of the bill which the Black duck does not have, and the wing patch is bluish-green; size is about the same. The Texas variety, known as the Mottled duck, is found as far north as Kansas, and differs very slightly.

IIabitat - Southern United States. There 
are some three varieties of this bird, differing only in minor points, due doubtless to climatic influences. They seem to prefer the fresh water more than do the Black duck, which they so closely resemble that the ordinary sportsman will hardly recognize the difference withont close observation, though the distinction is well marker, being somewhat lighter in general color than its near relative.

\section{GADWALL. GRAY DUCK. \\ Anas strepera.}

Predominating color, graty with a yellow tinge ; back and breast darker, nearly brown. The scaly appearance noted in No.9 is very noticealle in this variety, as the edges of the feathers are nearly white. Wing patch white. Bill blue-black, in the female lighter and blotched with orange. Iegs orange, with dark webs. Eyes red-brown. Belly white, with gray lines. Extent of wings, a little less than 3 feet. Length of bird a little less than 2 feet, being a trifle smaller than either No. 8 or No. 9 . Weight about 2 lbs.

Habitat - Northern Hemisphere in general, principally in the interior, as it prefer's the fresh water. These birds do not go in large flocks, but they make up for numbers by the noise they make; a small flock will create more disturbance than a raft of Black duck. They are comparatively bold; are clean feeders, and are excellent eating. 


\section{BALDPATE. AMERICAN WIDGEON. Anas americana.}

Predominating color, gray with fine wavy lines of darker, belly white, as is also the bocly of the wing, while the tips are brownishgray. Wing patch green. The body of the head is buff color, shaded with greenishhlack and brick-red, and the old drakes have a broad distinct patch of green on the sides of the hearl, backwards from the eye; the distinguishing feature, howerer, is the distinctly white forehearl, which is present to a greater or less extent in all the different ages. The females and the young males are clarker in general tone ancl the shell markings are more distinct, while the white crown is less so. There can be no mistake in identifying' the species however, from the great amount of white on the wings and under parts. About the same size as No. 11; will average smaller. Bill bluish-gray. Feet a trifle duller. Eyes brown. A very difficult bird to describe, from its great variability in clifferent ages.

Halbitat-North America at large, but probahly less plentiful in New England than in the Fouthem states and the Mississippi Valley. In fact the local gumner's hardly know the bird.

They are shoal-water lirds, and feed upon acpuatic plants. They have the curious habit of thieving the succulent (leep-water plants 
from the deep-diver's and hastening out of reach before they recover from their surprise. They winter on our southern borcler, where they congregate in large flocks.

On the Pacific coast we sometimes find a bircl almost identical in appearance, hut the top of the head is creamy instead of white ; there is scarcely a shade of green on the sides of the head, which is cinnamon-red instead of grayish. This is the European widgeon, and is only an occasional visitor. It is reported to be not uneommon on the Pamlico and Albemarle Sounds.

\section{GREEN-WINGED TEAL.}

\section{Anas carotinensis.}

Prevailing color gray: moler parts white. Old drakes have a rich chestnut-brown hearl and neck. with green marking, as in the Baldpate. Breast dotted with dark; wing spot green. The females and young males have dark and light lnown as their predominating colors, and sulficiently resemble the old males that there need be no mistake in their idlentification. Smaller than any of the other ducks, the length being only a little orer a foot and the extent less than 2 feet. Bill black; feet light blue; eyes brown.

Habitat - Entire North American continent.

Although small, it is one of our finest game birds and one of the most prolific. They are 
found generally in small flocks on the edges of shallow ponds. They are finely flavored and a good game bird. The European variety, closely resembling the American, is a rare visitor to our Nortl Atlantic coast.

\section{BLUE-WINGED TEAL. Anas discors.}

Predominating color brown, under parts lighter than the upper; head lead-color, nearly black on crown with a white crescent in front of each eye. The feathers of the back have edgings of the lighter color, and the breast is spotted with the darker; wings sky-blue with green patch; bill grayish-black; feet yellow; eyes brown. A little larger than No. 13. Weight 12 ozs.

Habitat - During migrations this bird corers the greater part of the country east of the Rocky Mountains. Its habits are very much like the Green-wing, and like them they are very swift of flight. While feeding they are very unsuspicious and can be easily ajproached with a due amount of caution.

\section{CINNAMION 'TEAL.}

\section{Anas cyanoptera.}

The female is very similar to No. 1t, but the male is of a rich cimmamon-brown color; wings blue as in No. 14, and with green patch. 
About the same size as the Blue-wing; bill black; feet orange; eyes orange in male, brown in female and young.

Habitat - Rocky Mountains, north to Oregon. A South American variety, rarely found outside the above limits.

\section{SIIOVELLER. SIIOVEL-BILL.}

\section{Spatula clypeata.}

Broarl-bill; although this latter name is more often applied to the Ruddy duck. Back of male black, with each feather tipned with a lighter color. Head dirk glossy green; breast white; belly chestnut-brown with a

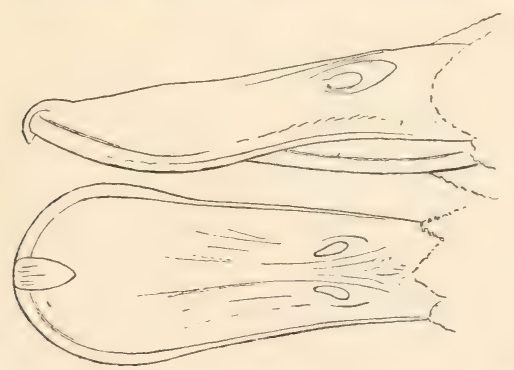

purple shade; shoulders blue; wing spot green, bordered with white; tips blackish ; a white spot at each side of the tail; bill brown, and broad at the tip, which is twice as large as at the base; feet and legs red ; eyes reddish-yellow. 'The female and young' males are of a soft brown color, shaded? with lighter', 
as is usual in nearly all the ducks. Eyes yellow. Size aloout that of the Wirlgeon (No. 12), but a trifle smaller.

Habitat - Entire continent; but rare on the Atlantic coast. Very abundant in Florida in the winter. 'They delight in shallow pools, where they float, with their heads under water the most of the time, feeding upon the aquatic grasses and insects. Audubon pronounced them as the finest cluck for the table in America, even better than the noted Canvas-back. Their flesh is very finely flavored, and, after all, much of the fame of the latter is due to a customary idea.

\section{PINTAIL. GRAY DUCK. \\ Dafila acuta.}

Back of male bird gray, marked with wavy white lines; under parts white. IVings dark, speculum green, with coppery reflections. Head and upper part of neck dark brown. The tail is from 5 to 9 inches long, forming a distinctive feature. Bill black, edged with gray; feet gray-blue; eyes brown; size a little smaller than the Mallard, but more gracefully formed. Weight about 2 lbs. The female and young drakes are somewhat smaller, and lack the long tail. 'The back is brown, mottled with cream-color, while the under parts are light yellow. This plumage is liable to be somewhat varied, as they often cross with the Mallard. 
Habitat - West of the Alleghenys; not at all common east, as they prefer the shallow ponds, where the bottoms are corered with herbage. C. J. Marnard says that there are more of these duckis in Florida in the winter than of all other species put together. They seldom or never dive, but stand nearly on end, feet in the air, while pulling the roots from the bottom. They are very swift of flight and quite wary.

\section{WOOD DUCK. SUMIIER DUCK.}

\section{Aix sponsa.}

Back of drake rery dark brown, belly white, sides marked with gray; breast is reddish-brown with triangular white spots. 'The top of head and its crest, which is quite long, is dark green, with purple reflections. The throat is white and a section of it branches up toward the eye. A line of white extends backward on each sicle of the head from the face of the bill and another from just behind the eye. Bill black, with pinkish-white sides, and red at base; feet orange; eyes red. In June the male changes its plumage, and then resembles the female, but by October they have nearly regained their full plumage ; during this period, it is said that the drakes flock together. The female would hardly be recognizable as the mate of its gaudily dressed partner. The back is slaty-brown and the belly white; the breast and sides of body are 
light brown, mottled with dark gray and brown and there is no crest, but the feather's of the nape are elongated.

Habitat - Temperate North America.

This bird, formerly so plentiful, breeding as it did near all the wooded streams of the United States, is yearly becoming more scarce. 'Ten year's ago there was scarcely a stream in New England but had its pair, which lived and reared their young near its banks; but the beantiful plumage of the male bird was a bait for the sportsman, and the tender and savory flesh for the epicure. In the fall, when they cram their crops to the utmost with acorns, they are in the finest flavor and fit for a monarch. Now these places know them not, and they are plentiful only in the more sparsely settled localities.

\section{RED-IIEAD. AMERICAN POCHARD. Aythya americana.}

Back of male mixed black and white in very fine zig-zag lines, giving it a gray appearance; belly gray, gradually verging into the color of the back ; wings darker ; breast black; head and neck rich chestnut-brown; bill bluish, broad and flattened; feet gray-blue with dark webs; eyes orange. The female and young are much like the above, but the head is clull brown, lighter near the bill, and the back is brown, with no zig-zag markings ; eyes yellow; length a little less than 3 feet; extent of wings a little less than 2 feet. 
Habitat-Aretics to the Gulf. This is like the next, a deep-water duck, culling its food from the bottom and there gathering molluskis, fishes, and sulmmarine plants. It is often mistaken for the famous ('anvats-back, which it much resembles and for which it is often sold, as the novice can scarcely distinguish the rlifference, though it is plainly marked. The hill is hroarler and more flattened, and blue, with a black belt at end, while in the latter it is blackish throughout.

\section{CANVAS-BACK.}

Aythya vallisneria.

Resembles No. 1! very much, in fact the Red-head is often sold for this hird, but the head is closer feathered and the bill black, not so broad, and higher at the hase : the back is lighter in general color: eyes of male red ; of female red-brown; the size is a trifle larger than the Red-head.

Halbitat - Same lange as the Red-hearl, and its habits aplly as well in one case as the other. 'They were formerly abundant on the Atlantic coast, and while feeding in the Chesapeake Bay on the wild celery (I'allisneria spiralis), they attained a flaror which gave them a world-wide reputation as a table bird, which was, in a measure, moleserverl, and for this reason were slaughtered in thousands. In consequence they are now getting scarce in this locality, and the principal supply comes 
from the Mississippi Valley. These Western birds are not posisessed of the same delicacy of those from the Chesalpeake, and it is a matter of serious doult whether it is ever the peer of the shoveller, much more the superior. Aurlubon pronomuces in favor of the latter, while IVilson inclines to the former, but Aurubon wis original, while WVilson, with all his genius, from which I would not for the world detract one ista, was more swayed by other's opinions. 'These bircls are famous for' their diving and swimming qualities, and when wounded will often escape in this way, oftentimes seizing a sunken root with a death grip and never arising to the surface.

21. AMERICAN SCAUP DUCK. BLUE-BILL. BROAD-BILL. RAFTDUCK. Aythya marila nearctica.

Itearl, neck and breast black, in the drake, as is also the rump, tail, and body of wings; more inclined to a brownish shade in the female. Wing tips lighter than body, and the wing pateh is white; belly nearly white, and back black and white in zig-zag lines, much like the ('anvas-back; lill blue; feet black; eyes yellow. The female has a distinct white face, formed by a white ring around the upyer part of the bill and just back of it. Length about 20 inches. Extent of wings generally over 30 inches. 
IIabitat - North America in general. During the breeding season they frequent the inland ponds and marshes, but at other times they are not uncommon on all the salt-water bays of our coast. They are good divers and feed upon a general comise of aquatic liet.

The resemblance of this bird to the next is so close that they are sometimes hardly distinguishable. Opinions vary as to their (pualities as food. Coues say they are good when fat. The gumners eat them, lut shore men will even eat gulls with gusto ; for my part, excuse me.

\section{LESSER SCAUP DUCK.}

\section{LITTLE BLUE-BILL.}

Aythya affinis.

This bird is not easily distinguished from No. 21, except that it is somewhat smaller, measuring 15 to 18 inches in length, and under 30 inches in extent.

Ilabitat - Same as last, which it resembles almost exactly, except for being a little smaller. Like them they form rafts or flocks on the water, and when they rise make the air resound with the sound of their wings, but unlike them they prefer the more brackish water of the river mouths, and the great rivers and ponds of the interior. 


\section{RING-NECKED DUCK. RINGED-NECK SCAUP. Aythya collaris.}

Bill dirker colored than No. 22, brown ring around the neck of drake. Wing brownish-slate, wing patch gray, feet gray-blue, with darker webs. Bark nearly black. Female is more like No. 2.2, but the white face is not so apparent, and it has a white ring about the eye. This bird may also be distinguished from the other's by the bill; Nos. 21 and 2.2 have a plain blue bill, while No. 23 has black tip and base, and a narrow stripe of white defines the central blue band on either side.

Habitat - Generally about the same as the Little Scaup, which it also resembles in its habits. The same remarks aplyly to one as well as the other.

\section{AMERICAN GOLDEN-EYE. WHISTLER. GARRO'T.}

Glaucionetta clangula americana.

Head and back black, neck, breast and under parts white, with white markings on the wings. Hearl richly glossed with green. The distinctive feature of the Whistlers is the white patch on the sicle of the head at base of bill, but not touching it. In this species the spot is round. Length $1 \frac{1}{2}$ feet; ex- 
tent $2 \frac{1}{2}$ feet. Bill black, feet orange with dirk webs. Eyes bright yellow. The female has a brownish head withont the white spot, and the general tone is chuller, and the hird a little smaller.

Ilabitat - North America in general, and a common winter duck in the United states on both coasts and often in the interior.

A hird of beatutiful plumage in the male, an expert diver, fond of the flats.

() pinions differe ats the edibility of their Hesh. Coues says: - Meat baul- lank and tishy," but gunners on the New England coast eat them at times, and in olden times roast Whistler was often on the spit, and that when other ducks were more plentiful than now.

\section{BARROW'S GOLDEN-EYE. ROCKY MOLNTAIN WHISTLER.}

\section{Glaucionetta islandica.}

Iabitat - More northern than the last named, although it breeds in the Rocky MIountains. It comes in the winter down the coast and rivers, but is never so common as the other form. It is possible that it is often confounder with the common Whistler, but can be easily distinguished by the white spot before the eye, which is triangular in this species and oval in the other. There is also a crest on the top of the head and a parti- 
colored bill, while the gloss of the head is purple in the Barrow's and green in the American.

Both birds get their common name from the whistling sound given off by the wings in flight.

\section{BLFFLE-IIEAD. BCTTER-BALL. SPIRIT-DECK. DIPPER.}

\section{Charitonetta albeola.}

Back and head of male black, the latter with a large white patch extending from the eye back to the erlge of the nape, forming a contimuous patch. 'The head is very puffy; hair' cut a la pompadour; neck and under parts white. The female has no puffed head; back brown, under parts dirty white, with white wing patch and on side of heat. Bill of drake dull blue; of female, dusky. Feet of drake flesli-color; of female, blue-gray, with dark webs. Eyes brown. Weight about 18 ozs.; female a little less.

Habitat - North America at large. The male of this lincl is a beauty and no mistake, but Heaven help the man who tries to eat one. I can eat almost anything when I am hungry, but I prefer to hunger rather than eat a Dipler. 'They can dive like a Kanaka, and are only excelled by the little (xirebe (the hell-diver of the vernacular'), which can elucle a rifle ball and dodge a sumbeam. 'Their' habits are like their relatives, the Golden-eyes. 


\section{OLD-SQLAII. LONG-TAIL DECK. SOL-SOLTHERLT. COCKAWEE.}

\section{Clangula hyemalis.}

Prectominating color of the drake, white; breast, back and wings black, the latter with a patch of long white feather's hearl with a patch of gray-blue about the eyes, sharling into black toward the back of neck. Two long black feathers protrucle from the centre of the tail. In the spring the white feathers of the side are mingled with redelish ones. Bill black, tipperl with orange; very light when fresh. Fect blue; eres red. Female brown on back, sharled white beneath; no long feather's on tail nor shoulders ; bill and feet dusky-greenish; eyes yellow. Weight about 21 bs. A rerr hatel bird to describe, as there are so many variations to its plumage in its different forms. The summer and winter coats are very different in both sexes, but there is no chance of mistake after one of the birds have once been noted.

Habitat - Northern Hemisphere.

Of all the inveterate old gabblei's, this bird carries off the palm; a good-for-nothing tattling set of old gosipiss. 'The flesh is rank and fishy, as they are fish feeders, but the males are very pretty in their dresses of black and white, declied ont with drab and brown. They are often shot for their beauty, but never, I think, for food. 


\section{HARLEQUIN DUCK. LORD AND LAIY. PAINTED DLCK. Histrionicus histrionicus.}

Sexes very unlike. Predominating color of the drake dull puxple, darker on the upper parts than on the lower, changing to chestnut on the sides; marked with white as follows: a patch in front of eye, curling over it toward the crown, where it changes to brown; a round spot on side of head, just below which is a long patch on sicle of neck; a collar about the neck, and patches on wings and each side of the root of the tail, hesides a white crescent on breast in front of each wing; bill greenish-yellow; feet gray-blue with dark wels ; eyes red-brown. Predominating color of female brownisli-gray, to whitish on under parts; a whitish spot hefore the eye and behind the ear ; bill and feet hluish ; eyes brown; length $1 \frac{1}{2}$ feet or a little less; extent of wings 2 feet or over.

IIabitat - Northern hemisphere, south in winter to latitude $40^{\circ}$ north. These beautiful cluckis are not common farther south tham the coast of Maine on the east coast, and northern California on the west. They are well known to gumers principally from their larity and their variegated plumage, tham from any qualities as a food bird. The female is much smaller, and entirely different in general appearance from the male. 


\section{LABRADOR DUCK. PIED DUCK. \\ Camptolaimus labradorius.}

Former habitat Atlantic coast, lreeding from Labrador northward, ilescending in winter southwarl to the Chesapeake. The adult male, a rather large duck, is in general, black, head and upper neck white, with a strip of black on the cromn and around the neck; wings pied with black and white. Length about 20 inches. Extent about 30 inches. Weight nearly 2 lls. Female is a sort of dippled dark gray, lighter on the wings.

This bird is now nearly extinct if not quite so, but only forty years ago they were on sale in our markets, and there is a bare chance that another may yet be taken. Strange as it may seem, this hird has disappeared during that space of time, and now bids fair to follow in the footsteps of the Great iuk. 'The main opportunity of securing one more of these birds (there are only 38 in existence, and these are valued at ahout $\$ 500$ each), seems. to be either in finding one among the treasured trophies of some coast gumner of the north, or that one may ret be taken among the flockis which come down our coast in the winter, and this note is written in the hopes that gumer's will heed the miversal cry and look out for them. 


\section{AMERICAN FIDER. SEA IOUCK.}

\section{Somateria dresseri.}

Predominating color of drake white; r'ump), tail and moler parts black; top of hearl blueblack; back of hearl sea-green. The bill, which is dirty-yellow, runs on each side far up toward the eye. Feet greenish; eyes brown. Length 2 feet and over ; extent 3 to $3 \frac{1}{2}$ feet. Female very unlilie the male. Predominating color brown or tan, barred all over with black.

Habitat - North Atlantic coast; south in winter to Long Island Sound. They principally frequent the rocky shores of our coast, but occasionally are seen on the large lakes. Their flesh is not particularly delicious at all times, but is supposed to be palatable under favorable conditions. The down from the breast is of well-known superior quality.

\section{PACIFIC EIDER.}

Somateria v-nigra.

Ialbitat - North Pacific coast, south to California. The habits are much the same as those of No. 30, and the same remarkis will apply to both. The distinctive feature which divides them is that this latter bird has a black V-shaped mark on the throat. 


\section{KING EIDER.}

\section{Somateria spectabilis.}

Inabitat-Circumpolar ; south in winter, in very small numbers, to lat. $40^{\circ} \mathrm{N}$.

This hind raries much in alpearance from the others of the family, and mat he distinguished by the presence of the black I throat mark, from the Eastern variety, and from the Wrestern hy the different conitiguration of the bill, especially in the summer.

\section{AMERICAN SCOTER. SEA (')(OT. ISLTTER-BILL.}

\section{Oidemia americana.}

Color of clrake entirely black; bill very peculiar, having a verr prom omuced hump at the base, which is yellow, changing to liack on the tip. Weight $2 \frac{1}{2}$ to 3 llos. The female is smaller, dusky brown, paler beneath, without hump) on the hill ; feet dark ; eyes brown.

Habitat - North American coast and Great Lakes.

I have now touched on ground "where angels might fear to tread," for none are so jealous of their farorite bird as the " coot shooter," and there is no family so diversely named and regarded by mankind. A young bircl may be a luscious dish for an epicure, and "coot stew" is famous, but an old bird 
is simply infamous in flavor, and I never saw a bird so young as to equal a stew of old boots flavoreil with fish oil. Pardon me, friends, devotees of the wily coot, my education has been sadly neglected. I can eat sculpin, but do not ask me to eat coot.

The females and young of this bird, and also No.35 are known to gunners collectively as gray coot, and weigh from 2 to 3 lbs.

\section{WHITE-WINGED SCOTER. BULL COOT.}

\section{Oidemia deglandi.}

Plumage of drake black, with white spot on wing and another under the eye; bill black, with knob at base, but not so large as No. 33 ; eyes white; feet red, with black

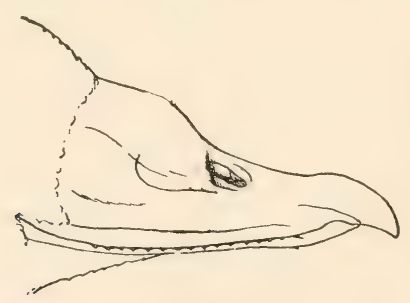

welss. Female sooty-brown, with same markings, except bill is less bulging, and there is more white on the head; eyes brown. Length $1 \frac{2}{3}$ feet; extent over 3 feet. Weight 3 to 4 lbs. 
Habitat - About the same as the other coots, and resembling them in general habits.

\section{SLRF SCOTER. SHLNK-IIEAD. \\ Oidemia perspicillata.}

Male hird black, with white spot on forehearl, and another on back of neck; bill prominent, orange at top and tip, mottled with biack at base, a large black spot at base on "ach side, in front of which is a bluish-white fatch; eyes white; feet orange, wels dark. Female hown, whitish on sirles of heal and heneath; bill dark gray ; feet dirty-rellow, wehs hlack; eves hown. Wright alont $2 \frac{1}{4}$ to $3 \frac{1}{2}$ lbs. A little smaller than No. 34.

This seems to be the most plentiful of this family, at least about the shores of New England. where they are most sought for by gurners. but the comparison is rendered variable by local conditions.

In Massachusetts Bay - the Mecea of " cooters" - they strike in about August 15 and the flight is orer about September 20 , but the bircls stay about all winter. They feed upon the flats, but are then extremely difficult of approach by floating. They are mostly shot outside the harbor's as they fly by and are called down by decoys. C'uriously enough, although they reach the bay so early, they are seldom seen below Cape Cod until October 1. 


\section{RUDDY DUCK. BLUE-BILL. BROAD-BILL.}

Erismatura rubida.

Butter-lanll. IBut this latter name must not confound it with the Buffle-head.

Predominating color of full plumaged male, rich brownish-red. Top of head black, throat and sides of hearl white, belly silvery or graywhite. Generally this bird is brownish, light beneath. Bill and feet bluish. Eyes redbrown. Easily distinguished from ducks of its size, by its broud, flat boly, shovel-bill, and short neck and legs. Length $1 \frac{1}{3}$ feet. Extent less than 2 feet.

It habits the entire continent, and is now better known on inland waters than on the eastern coast.

They are easy of approach but gently slicle beneath the water on slight provocation. Expert divers, they swim for some distance beneath the water, realyearing out of gunshot. They feed upon seeds, roots and shellfish, and are very edible, being fairly well flavored, fat and juicy. When food is plentiful, they gorge themselves to the utmost, and then are in prime condition for cooking. 


\section{LESSER SNOW GOOSE.}

Chen hyperborea.

\section{GREATER SNOW GOOSE. WHITE BRANT. WAVEY.}

Chen hyperborea nivalis.

Color white, wing tips black, heal stamed with rusty. Bill reel, with black on erlge of mouth. Leg's same eolor. Eyes dark brown. The young birds look like Nंo. 39. Weight is to 61 ibs.

Halbits the western sections and interior of North America, a few visiting the Atlantic coast in the winter, common in the interior.

These two bircls are so near alike that I do not attempt to separate any notes on the two varieties. The lesser variety is only ahout 211 s. lighter than the other, and grading up to it. so that it is nearly impossible to distinguish them. Their coloration is irlentical. The bird which is found in the East is generally, perhaps invarial,y, the larger form.

In the Ealst they are inuch in habit like other geese, feeding in the bay's and harbon's, though I have never heard of their being shot in the ponds. I see no reason why they should not he, as in the West they swarm the prairies to such an extent as to clestroy whole fields of wheat.

The flesh is clark colored, and not so finely flavored as some of its relations. 
A near for'm is the

39. BLUE GOOSE.

Chen corulescens.

Which was long considered but the young of No. 38, or a colored phase of the same lirel. It is about the size of No. 37, and with about the same habits. Heal white, body dusky gray-blue, shading into lighter below. Tips of wings black. Not common.

\section{ROSS'S SNOW GOOSE. HORNED IVAVEY.}

\section{Chen rossii.}

This little goose, not linger than a Mallard, is an Arctic form, descending in winter to the lower latitudes. Its habits and characteristics are but little clifferent from other's of the family.

41. AMERICAN WHITE-FRONTED GOOSE. LAUGHING GOOSE.

Anser albifrons gambeli.

Predominating color graysh-brown, under parts whitish, blotched with black; this white extends backward around the base of tail, which is black, tipped with white. The dark color is mottled with brown on the tips of the feathers. 'The characteristic mark of the birel is the white forehead. Bill smooth, pink; feet yellow, eyes brown. About the same size as 
No. 38. The young birds are darker and lack the white forehead, and the bill and feet are darker.

This bird is quite common on the Pacifie coast and the Mississippi valley; selilom coning east, although they are occasional visitor's. They are more shy thin the other geese and hug to inacessible places rery closely. 'They feed mostly upon arpuatic plants and their flesh is of fine flavor.

\section{CANADA GOOSE.}

\section{Branta canadensis.}

Upper parts hrownish-oray, shatling to a lighter below; bill, hearl, neck and legs black. I broar white patch on the chin, extending mp) to nape, and white orere and under the tail, eyes hrown; extent, 5 feet, length. 3 feet, weight 8 to 15 lls. when in good condition.

The common wild goose of the entire country, breeding in the north and going south in winter to the Gulf of Mexico. 'Their migratory flights are strong and rappid, and their $T^{\prime}$-shaped steins passing orer latve drawn out many a firmer to try a shot, and many a one has fallen in this war, and many more have been decored to blinds on the shores of the ponds where they had stopled to rest and feerl, and never gone on with the rest of the flight. 'Their' flesh is justly' esteemed for the talle, and their feathers for beds and pillows. 


\section{HUTCHINS'S GOOSE.}

\section{Branta canadensis hutchinsii.}

This is a small variety of No. 42, about the size of No. 38, and frequents the western country more than the east. Another variety is the

\section{WHITE-CHEEKED GOOSE.}

Branta canadensis occidentalis.

Which is a Pacific coast bird; and still another,

\section{CACKLING GOOSE.}

Branta canadensis minima.

Smaller than any of the other's and from the same section.

There is no doubt that all these varieties are entitled to separate mention, but for our purpose they are about the same thing. Every gumner likes to know, however, what his game is, and for purposes of distinction I give Cones's method of separating the varieties : -

Large, no collar of white on neck, No. 42. Small, "6 " " 6 " $\quad$ " 40. Large, with " " 6 " 6 " No. 44. Small 6 66 $\quad 6{ }^{6} \quad 66 \quad$ No. 45. 


\section{BRANT. BRANT GOOSE. \\ Branta bernicla.}

Hearl, neck, batek and wings blatek, some of the quills of latter, whitish on the inside. This color is in some platees sharled with brown. Curler parts arar, harred with blackish; back of legs it is white, which color extends up over the base of the tail. Sides of neek marked with several white streaks. Bill and feet black, eyes brown. Length 2 feet, extent $t$ feet.

This bind hathits the Atlantic coatst, coming south to the Lniterl states. only in the migrattions, as far ats Florirlat. They coulleret in litroe flocks in the shoal waters, where they feed upon the shell-fish, pliants, ete. They selelom dive when feeding. hut stancling nearly on emol, they pull their ford fiom the botom. They are wary and aroid the shore exeepent when feeding. 'The sambl hats are often black with them while they are dusting. 'Thein' flesh is very edible, and they are much esteemed for both food and sport.

\section{BLACK BRAN'T.}

Branta nigricans.

Much like No. 46 , but the black of the neck runs down on the breast, and the white marks on the neck nearly form a collar. Size of No. Hi, and is found on both coasts, but most plentiful on the Pacific; in fact, it is really rare on the Atlantic. 


\section{8. * EMPEROR GOOSE. PAIN'TED GOOSE.}

Philacte canagica.

Predominating color light blue, with wary marks of lilac, and clearly defined shell-shaped markings of black. Itead, back of neck and tail white; throat black, speckled with white; feet flesh-color; eyes brown.

II albitat-Extreme northwest, coming south to Aliskit, and lower in the winter. I little larger hird than the Brant. A sea-goose, and not worth the powrer used to kill it for its edible qualities, as it is rank and fishy.

\section{BLACK-BELLIED TREE-DUC'K.}

\section{Dendrocygna autumnalis.}

Predominating color black; head and neck chocolate, lighter on the chin, white nuder tail, on the flanks and on wing; bill red ; feet pink; length 1 is feet; extent : $)$ feet or more. Lives on the Rio Grande. A very good market bird.

'There is another of these peculiar ducks, the

\section{FULVOUS TREE-DUCK.}

\section{Dendrocygna fulva.}

Which is yellowish-hrown, darker on the hear, $n 0$ white on wing; black bill and bluish feet; abont the same size and same locality, but comes farther up the Gulf coast. 


\section{WHISTLING SWAN.}

\section{Olor columbianus.}

Color white in full plumage, sometimes with rusty markings about the hearl: hill and feet black, the former with a small yellow spot in front of the ere; length under ; feet; extent 6 to 7 feet. Yommg hirds are smaller, ashygray, with a tint of redelish on the head ; hill and feet flesh-color.

They halit the entire continent of North America, hut are lare on the North Atlantic coast. They feed on aquatic plants and insects, which they glean from the hottom with their long necks ever and anon poked up in the air and then thrust down to the mud, but they never dive while feerling. It is a much debated question among sportsmen naturalists whether they ever dive or not; they are, however, credited with this feat when in danger, hut they are seldom apporached very chosely without taking wing. Their volee is lond, and they are exceedingly noisy when fercling, but it is neerlless to say that ". the sweet walbling of the dying swatn "is " all in your eye." They courd not warble if they wanted to.

\section{TRUMPETER SWAN.}

\section{Olor buccinator.}

This bird is hardly to be distinguished from No. o1 except loy its larger size, heing about 5 feet long and 8 feet in extent of wings, 
weighing about 40 llss. There is one point of difference in full-grown birds, which should be constant, viz., No.51 has twenty feather's in the tail and No. 52 has twenty-four. Both these birds are good eating, and sportsmen need not quibble over the feather's in the tail if they have an opportunity to bring one to bag, for they are the cream of bird-shooting. 


\section{THE WADERS.}

\section{3. * WHOOPING CRANE.}

\section{Gius americana.}

Old birds white, with black wing-tips: bill greenish; legs blated hearl naked, calmine color, sparsely covered with hair-lilie blatk feathers: eres rellow. The young birds are grayish-white, with patches of cinnatmon-brown: head feathered. of the same brown color. Length $f \frac{1}{33}$ feet : extent, $7 \frac{1}{2}$ feet, weight 12 to 30 llis. Female a little smaller. It principally hathits the soutleren sitates and the Mississiplei Valley. Its voice is loud and can be heard a long distance. These birks feed upon grains, regetables. worms, mice, reptiles, or in fact almost anything which comes within their reach. They are strong flier's and keel) ul a continuous croak as they carry their Indian file through the air. 'They are exceedingly wary, and are best shot from hlinds, as ther come to feed in the shores of the shallow ponds of the South.

I scarcely am able to distinctively class this bird and its succeeding allies as game loirds, although their flesh is not had eating. and is much relished by some, so I have admitted 
them under the hypothetical list, as almost any sportsman would (hop) them if he hat an opportunity.

\section{4. * LITTLE BROWN CRANE. \\ Gins canadensis.}

Plumage of old bird leatloray; wing-tips a little darlier. Ifead nearly Inare, as in No. 53, crimson; bill and feet black; eyes red. Young, with heal feathered, and plumage patched with rusty-lnown. Lemgth :3! feet. Extent, 6 fect and over. The only record of the weight of this hird is one shot in Texas, viz., $11 \frac{7}{\mathrm{~s}}$ los., lout it is stated that they weigh as much as 17 lbs.

The habits of this bird are very similar to No. 53, and, like them, they exhibit strange antics in the mating season. In fact they conduct a war dince, in which the females join as well, and the whooping and circling are equal to a country dance.

There is another bird which is closely related - the

\section{5. * SANDHILL CRANE. COMION BROWN CRANE. \\ Grus mexicana.}

Plumage and habits exactly like the last, and in fact it was always considered one speeies until very lately, but the variety 
maker's have recided that they shall be divorced, hasing their derere ujom the difference in size of birds. The size of this hirel

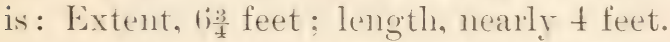

\section{j) KING RAIL. REI)-BREAST RAIL. FRESH-WATER MARSH-HEN.}

\section{Rallus elegans.}

P'redominating color olive-lnown, streaked with very lark hown; plain brown on top of head and neck; chestnut-hrown on wings; reddish-lown below; lighter on the belly. 'I he sides are darker and streaked with white. Length, 1! feet: extent, 2 feet. Bill and feet rellow-lomwn: Pes reel. Is foumd in the fresh-water manshes of the eastern United States, south of lat. $40^{\circ}$ N., where it skulks and hides in the high grass and reeds, and can even talie to the water on alpuroatel of the dog, flying principally by night, and not starting easily when apjuratched. They feed upon insects, reptiles and seeds of the aquatic plants and grasses. Their flesh is good, well flavored, and this, combined with their size, makes them a farorite game birk.

\section{CLAPPER RAIL. SALT-WATER MARSH-HEN.}

Rallus longirostris crepitans.

Varieties-California ('lapper Rail, Lomisiana Clapper Rail. 
General appearance something like No. 56, but comsiderably smaller, and a little lighter in general tone. 'The lower parts are more inclined to a grayish color, as, in fact, is the whole bird. Length 15 inches ; extent aloout 20 inches.

The two varieties are only such as are produced by difference of climate and local surroundings, and are so nearly alike, that the average sportsman could not distinguish them unless laid side by side. It may be very well for our ultra scientific workers to devote their time to finding varieties, and these varieties may be valid and constant, but it seems to the average sportsman that they would be better employed otherwise.

These birds frequent the salt and brackish water marshes of our shores on both coasts, on about the same range as No. 56. They take to the water more freely even than the fresh-water bird, but afford excellent sport if properly hunted. The most approved plan is to place a good poler in the stern of a skiff, while the gumer stands in the bow, and is propelled through the reeds which the birds oceupy as a home. This sport requires a quick eye and a steady hand and balance, while the poler must be steady and quick to " mark" the birds as they fall.

In the autumn they are very good eating, as they are clean feeder's themselves at this season. 


\section{VIRGLNIA RAIL.}

\section{Rallus virginianus.}

Not often known to sportsmen as being more than a smaller bird of No. 56 , or a clarti colored bind of No. 59. In plumage it is almost an exact copy on a small scale of $\mathrm{No}$. 56, measuring about 9 inches in length and $13 \frac{1}{2}$ in extent.

They are more or less abundant in the marshes, both salt and fresh, from Massachusetts southward, of course leaving its more northern range when cold weather aplorothes. They also are found in small numbers on the western coast, and are not rare in the interior. Their home alpear's to be in the marshes from New York to Carolina, and lere they are found in consirlerable numbers, affording good sport, hut there is not meat enough upon them to make them of much value as food. The old saying "as thin as a rail," might have been a comparison with this bird, without deviation from the sense. Our birds in the north in summer are not near so numerous as the succeeding species, but only a few gumers make any distinction, so that perhaps more are seen than are reported. 


\section{SORA. CAROLINA RAIL. CAROLINA CRAKE.}

\section{Porzana carolina.}

Preslominating color rich yellowish-hrown, with numerous streaks and spots of white: hearl sharled with black. sirles lighter, harred with white, and belly nearly white. In rommere birks the colors are not so clearly rletinerl, the impression being that of a farled bird. Length about 9 inches; extent of wings about 1 foot or more; bill and legs yellowish-green; eyes brown.
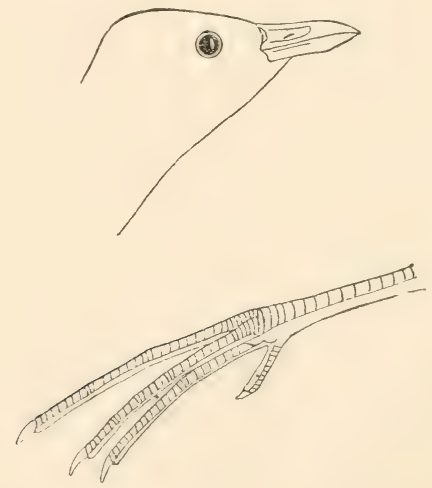

Inhabits the whole of North America; most common in the temperate regions, where it swarms in the reedy marshes. This is the common rail of gummers.and is cleservedly at favorite with them. Many are the hours 
spent in wading the meardows in pursuit of these bircls. They do not rise much more readily than others of the family, and have a way of skulking which is conclucive of bad language.

\section{YELLOW RAIL.}

Porzana noveboracensis.

Predominating color dull yellowish, barred with black and white; belly lighter, but with a more yellowish tinge than any of the other varieties. Bill darker than the others; feet and leg's flesh-colored; eves hazel. A smaller bird, about 6 inches long and a foot or less in extent. This birl is not common anywhere, more reserved in his habits, not so noisy, and moves about mostly in the twilight. It ranges all over the continent.

\section{BLACK RAIL. \\ Porzana jamaicensis.}

Very dark colored, and finely speckled with white, with some lars; ; bill black; legs and feet greenish-yellow: eyes red. Smaller than any of the other's. being under 6 inches long and about 11 inches in extent. Also widely distributed, but not commonly seen.

The reason that I note these birds is that sportsmen may look for them and report their capture that their relative alumblance may be better known. 
The succeeding three birds I arhit to this list muler protest, as I do not consider them game in any sense of the word, although I would not cast reflection upon any man who shoots them. Perhaps a man may be pardoned for taking that which is pleasing to the artistic sense by reason of its beantiful colors or graceful form, as well as he who caters to the demands of an epicurean appetite. These birds are beautiful; they are sometimes eaten ; they are shot, hence they are here at the solicitation of parties interested.

\section{2. * PURPLE GALLINULE. BLUE MUD-HEN.}

\section{Ionornis martinica.}

Color ahove, greenish shaded with the purple of the head and under parts, clarker in belly and wings; the bill is red, tipped yellow, and above it is a sort of shield of blue color; legs yellow. South Atlantic and Giulf Sitates, sometimes north to lat. $40^{\circ}$. Length 1 foot, extent nearly 2 feet. A beantiful bird with many of the characteristics of the Coots, and like them living in the marshes and on the edges of the ponds.

I found one of these birds, in (aptivity, in possession of Mr. Andrew Downs, of Halifax, Nova scotia. It was aptured in that place, and when I saw it there in 188?, was reasonably tame. It would feed npon the seeds 
thrown in the aviary for the other hirch, and would come down and eat with them. It patsised a portion of the time in the branches of a small tree. which occupied the centre. and roosted there at night, flacing its lomg toes over the sprearling twigs where they forked, as it could not clasple its toes aromil the branches.

\section{3. * FLORIDA GALLINULE.}

\section{Gallinula galeata.}

Batck dark slate-color; hearl, neck and breast brownish or blatek, becoming lighter on the belly; edges of wing white, with stripes of same color on the sicles: bill. which has a helmet like the last named species, is red with green tip); legs greenish : "yess reel. hrown in roung birds. Weight alout 1 lh.: a little larger birel than the last. and inhabiting about

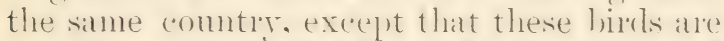
regular visitors to the North for hreedling. and they are more inland in their habits. Like the Rails, they dangle their feet when they fly, and soon dirop.

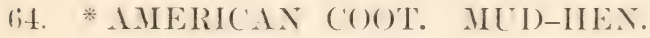 MEADOW-HEN.}

\section{Fulica americana.}

P'redominating color slate-blue; much darker on the hearl and neck, and tinged with brownish on the back; edge of wings white, 
and same color under the tail ; bill white, shaded with very dark red at tip and base. Legs greenish slate-color, and the joints of the

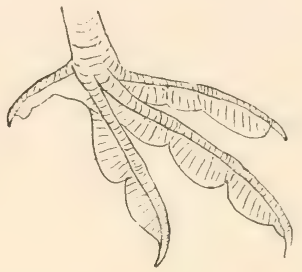

toes are furnished with broad flaps. Eyes reel. Length $1 \frac{1}{4}$ feet, extent 2 feet or over.

Its habits are very much like the Gallinules, inhabiting the marshes where the reeds are thick and the water plenty, and though they delight to sport in the open water, they quickly take to their reedy coverts when disturbed.

The reason that I objected to their introduction here was on account of the general verdict of gumner's that they were unfit for food. I never tried but once; I never shall try again; a thought of the first experience is enough, and in my younger days any one who would eat a "mill-hen" would eat crow. But I have found many advocates of the bird, as many as of the "Scat-Coot," another of the same ilk as regards epicurean tastes, and hence it is here. 


\subsection{RED PHALAROPE. WIILE-BIRI). Crymophitus fulicarius.}

The adult birds, in summer, are nearly miform wine-color on the uncler siles, anil the top of the head is almost hlatek. The rump is white, and the sirles of the hearl are the sime color, which matrings extemel over the back of the neck.

The bark has a tawny appearance. becantse the blatek feathers ate all erlered with hownish. The wing feathers are all marked with white. Eres brown. Legs hlack: hill rellowish at base, black at tip. Extent $1+\frac{1}{2}$ inches, length $7 \frac{1}{2}$ inches.

rportsmen seldom see this bird in the full plumage, ats they are then generally in the fat North, and they pass this seretion of the const without coming on shore, except hy aceiclent. about the first two weeks in May.

In winter they are more common in civil-

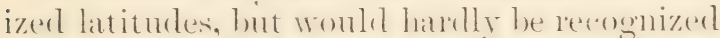
as the silne lirel. The bark is dark graly and the hearl and moler parts are nearly irhite. The white matkings on the wings alle also noticeable.

It is hardly fair to class these birds as shore-hirds, as they only come to land when l, lown in by heavy winds. I think that this bird is typically a seathird, and like the Stormy Petrel, makes its herl upon the waves, and sleeps with both eyes open. Doring heary northeast stoms, I liave had it reported 
thirty miles inland, but do not remember of ever hearing from it on other conditions.

\section{NORTHERN PHALAROPE.}

\section{Phalaropus lobatus.}

Whale-bird. Aclult birds in summer plumage are among our most beautiful bircls. 'The back is gray, banded with ochre-yellow. The under parts are white, and the neck is nearly encircled by a band of beautiful brownish-red. The wings are darker than the back, and plainly marked with a band of white. Eyes dark brown, bill and feet black. A trifle smaller than No. 65. They vary much from this plumage at different ages and seasons, the immature and winter birds being darker, and with the reddish neck less evirlent.

Much like No. 65 in general halbits, living mostly at sea, where they feed upon the floating weeds which carry the insects and small crustaceans which they favor. They occasionally go inland, and I think are found over the greater part of North America.

\section{WILSON'S PHALAROPE.}

\section{Phalaropus tricolor.}

Although all the Phalaropes are peculiar, in that the female is larger and more handsomely colored tham is the male, in none is it 
better exemplified than in this instance. Her neck is of a beautiful purplish-red sharling into velvety-black mpon the sides of the head. and this color can be traced latek to the wings: the lack and top, of heat are gray, becoming lighter at the bave of the tail, and the wing:s are slightly darker. Under parts pure white, breast shailed with buff. Eye's hrown, hill ancl feet black ; in size larger than either of the others of the family.

The male is much smaller, and, although lie has about the same markis, they are not so lright. The young, and the oild birds in winter, are light-gray alove, white beneath, and breast shaded darker.

These birds are exceedingly rare in the East, but quite common in the interior and westward.

They are to loe fomol on the ponts and marshes, and feed upon the insects and snails. All these lirds are at lome unon the water, but seldom or never dive.

This peculiarity of the sexes has given rise to many tales of female supremacy and domination, lut I fear that it will follow those of the song of the dying swan, "It is all in your eye."

Althongh, perhapss these hirds do not come distinctly within the linits of my definition of game, I never saw a sportsman who would not shoot one, and should consider him lardiing in mental capacity if he did not. 


\section{AMERICAN AVOCET. \\ Recurvirostra americama.}

Predominating color of the full plumaged binds is white, shading to a light brown on the neck and head, which seems to fade away, as winter approaches, to a clull gray. Wings black. The bill is extremely long, being about one-fifth the length of the whole bird, curved upward and black. Eyes light brown. Leg's very long; (lull blue. Extent 2! feet, length nearly $1 \frac{1}{2}$ feet.

This is a very curious bird, with its small body and long legs and bill, and parti-colored plumage. It feeds upon the aquatic insects which inhabit the shallow pools about which it loves to wade, immersing its long bill to the bottom, skimming the tol, in rapid succession, but they do also sometimes invade the grass fields, and wander over them in their search for food. They are now very rare in the Eastern United States, but seem to be common on the Pacific coast, and the Eastern markets often receive them in consignments of game from the Mississiplui Valley.

\section{BLACK-NECKED S'TILT. LONG SHANKS.}

\section{Himantopus mexicamus.}

Under side, forehearl and hase of tail white, and a large spot of same color on each side of the head back of the eye. 'Top of head, nape 
of neck, back and wings black; eyes and leg's red; bill black. 'The female and young birds are similar. but not so bright. Length 15 inches (variable on account of the length of the bill, which is from 21 to 3 inches long); extent $2 \frac{1}{2}$ feet.

Another long-leggerl birrl. and in hahits and distribution much like No. 68. lut more southerly. I have never seen this bird in the East, but it has been reported as occurring here, and doubtless is often in our markets. They are said to be social, feeding in large flocks, and not particularly wary.

\section{AMERICAN WOODCOCK.}

\section{Phitohela minor.}

There are a number of vernacular names for this bird, but I think that all will recognize it without difficulty. It is almost outside the

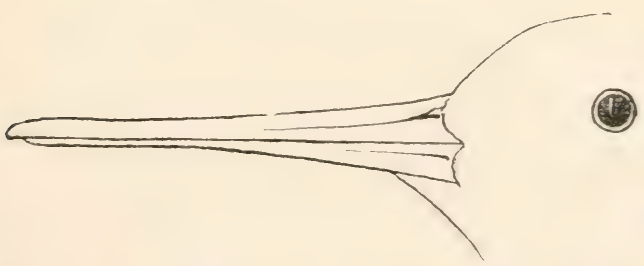

limits of the power of man to descrilue the magnificent marking of russet-brown and black which characterize the plumage of this 
birl, which, however, is easily recognizable from the long lill, short legs, stuh tail, and the position of the eyes, which are set high up) in the hearl, and far back; eyes black; bill and legrs flesh-colorerl. A verage weight about $6 \stackrel{1}{*}$ oz., hut have been taken weighing $9 \mathrm{oz}$. The habitat is Eastern North Anerica, north to Nova ficotia, which is now the finest place for this hind within reach of Eastern sportsmen. When I was there in the fall of 1889 , big bags were reported cluring the last of September, and while at Kentville, in the centre of the Province, one man brought in 28 birds taken by himself, and this did not appear to be comsidered out of the usual course of things. The sportsmen of the Southwest have apprarently a bountiful field in the low river bottoms which intersect that comntry. Many characterize this bircl as the "King" of Game IBirds," and he is entitled to surely a princely rank, if not the hearl.

There is a bird which has been taken in this country, one-third larger, lut with alout the same coloration and markings. 'This is the European IVoodeock, and is so very rare that a bind weighing over ? oz. should be preserved hy its fortunate captor, at least mutil it has been examined by ornithologists. I have a record of a woodcock weighing $12 \mathrm{oz}$. shot in Maine by a I)r. Gardner, hut I have been mathle to get more details. If not the European variety, I think it hearls the list for weight. 


\section{WILSON'S SNIPE.}

\section{Gallinago delicata.}

Known as English Snipre. but this latter name should hardly be used, for the European Snipe is not unknown on this sicle of the water.

Lpuer side varied brownish-blark and tawny; top of head black, with a tawny stripe down the middle; lneast and sides hrown, spotted with darkex: helly nearly white; eyes brown; feet and hill greenisli, the latter alout $2 \frac{3}{4}$ inches long: weight : 30 t! oz.; length 11 inches, extent 18 inches. The females will avelage a trifle less tham this, hut in all other particulats are similar to the male.

This birel inhahits the firesh marshes all over the continent, and its " s.caipe " and twisting flight is well known. This is probal)ly one of our most difficult bircls to shoot, as the moment it is fairly launched into the air it assumes an erratic course of flight productive of misises and mofanitr. Inalf-leg deep in the loger, with a crazy linel in fiont, aloout the aifest plan is to snay at the hirel as soon as it starts, and before it fairly gathers itself. 'This needs a quick ere and finger', and few men are sure of their bircl. They are most delicious birds for the table. 


\section{DOWITCHER.}

\section{RED-BREASTEI) SNIPE. BROWN-BACK.}

\section{Macrorhamphus griseus.}

Back brownish-black, mottled with light redclish-brown. Under parts of the same light color, shading to almost white on the belly; inside of wings white, marked with dusky; rump) white, showing very plainly during flight; tail black, barred with white. In winter the general tone is grayish, mottled with darker; white below, shaded with grayish on the breast, sides and throat; bill and leg's greenish-yellow; eyes dark reddishbrown; length about 11 inches, of which 21 inches is bill; extent 18 inches.

Supposed to inhabit only Eastern North America, and to be replaced in the IVest by a variety ( $M$. \% scolopaceus) which rarely comes East. 'This latter bird differ's only in averaging larger in size; the bill averages longer, and the belly is cinnamon-brown, instear of whitish. The variety makers have decreed that they shall be twain, and they are so lairl down; but I doubt if any average sportsman could distinguish them if laid side by side. 'They are both excellent game birds, and finely flavored, coming to decoys nicely, and alight in a bunch. Those that are not killed when a flock is fired upon, wheel around over their deal and wounded comrades, returning again and again, although 
repeatedly fired at. They frepuent the low flats and marshes, in tide water's following the ebb and flow.

\section{STILT SANDPIPER.}

\section{Nicropalama limantopus.}

Predominating color blitck, mottled with white and brown; a reshlish slot is on earch side of the head and also at dusky line. Tail gray, moler side redilish, moteled and barred with black and white; bill and feet dark green; eyes brown: length s! inches; extent about 16i inches: leas rery lomg. In winter they change to a gray color, mottled with lighter, and the leger are galer in color, with the under parts of breast and belly nearly white.

This bird may be considered as really not common anywhere. Their range extencls all orel the continent east of the Rockies, and the only blace where they may be considered as any way common is on the outlying points of oul Eastern onat about the first of dugust, when they rom the thats in (omplany with the sanderlings and tattlers.

\section{KNOT. REID-BIEAST PLOTER. Tringa cannetus.}

Sometimes called Robin sinipe, in common with No. 7.2. The yommeng ale known as gray

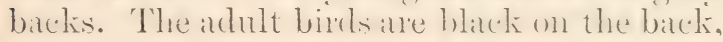


this eolor being broken by each feather being tipped with dirty white; breast and belly reddish-brown; tail gray, edged with white, short and even; bill stont and greenish-black; legs same color; eyes dark brown; extent 20 inches; length $10 \frac{\mathrm{i}}{2}$ inches.

One of our handsomest shore birds, inhabiting almost the whole worlil. In this comintry most common on the eastern coast, becoming rare westward, about the great rivers and lakes. The young birls are gray, marked with white above, and white, with a tinge of reddish, below. The markings on the back remind one of a succession of black and white semicircles. The spring migration passes lat. $40^{\circ} \mathrm{N}$. about May, and returns early in August, at which time they are very fat, and a bonne bouche for an epicure. They feed on shell-fish and marine crustaceans, which they pick up on the flats at low tide. They follow the flow of the waves upon the beach, rumning back and forth vivacionsly, and not seeming to mind when they were not quick enough to avoid an incoming wave, which took them from their feet and floated them along. The call of two sharp notes _ " Wheep, wheep" - is easily imitated, and they will often come within range, without blinds or decoys. 


\section{PURPLE SANDPIPER.}

\section{Tringa maritima.}

Predominating color of the birel which is generally known to sportsmen. is clark purple on upper parts and wings, the latter edged with white: breast lighter, eatch feather erloed with white. This colon extends along moler. the wings, but the belly is pure white: leass and bill flesh-color, the latter with hlack tiThe arlult breeding plumage is seldom seen, as the bird has a circumpolatr range, comming South only in the autumn and winter. 'Their' length is 9 inches, and extent about 16 inches. They are rarely seen before the first of october, and confine themselves to the rocki beaches, so that only a fow have ever seen them, and still fewer have shot them.

There are two hirds closely allied to this one. but they lobbably never come farther south than Alaska. I never saw one, and know nothing about them. 'They are the Aleutian and Prybilof sandpipers.

\section{PECTORAL SANDPIPER. GRASS-BIRD. JACK-SNIPE.}

\section{T'ringa maculata.}

The color of the upper parts is a mixture of ashy and resklish matkings on a dark brown gromid: under parts white: loreast and sides of neck duil light brown, marked with streaks 
of darker; patch of white under the chin, and a white line over the eye. 'The crown is a mixture of streaks of dark brown and light chestnut, and the nape of the neck is lighter, being streakerl with two shades of a clull yellowish cast. IVings darker than bocly. In the young fall birds the breast has more of a yellow tinge. Base of tail black; eyes brown; legs greenish-yellow. Length 9 inches; extent 17 inches.

'These birds are found all over the country, and I think are, as regards habits, pretty much the same wherever found. 'They love the low, muddy shores and flats, and the grassy meadows above tide water, feeding upon the crustaceans, grasshopper's and other small inseets.

They are a favorite game bird, although small; as they are quick of flight, somewhat resembling the snipe, and when "walked up" give a good shot an opportunity to show his skill. They are fine food, although small, and one never need throw them one side as useless.

There are two other birds closely allied to this, and to the casual observer differing but little. 'The first,

\section{WHITE-RUAPED SANIPIPER.}

\section{Tringa fuscicollis.}

Differs principally in the base of the tail being white; the breast without the dull color; and 
smaller size. Length $\tau_{2}^{1}$ inches, and extent 15 inches. Eyes brown, legs brownish. Found on the beaches as well as on the marshes.

Gumners on the east coast have found a smaller birel mingling with flocks of No. 76 , and they often have remalked that they are a different species. I have never been able to secure one of the smaller birds, but have no doubt that it will prove to be

\section{BAIRD'S SANDPIPER.}

Tringa bairdii.

Rate on the const lut plentiful in the interior, and cliffering from No. 76 in its smaller size, the length heing 7 inches, and extent of wings ahout 1 i) $\frac{1}{2}$ inches. The neck is the same color as the crown. The markings on the back hatre a tendency to yellow ish rather than chestnut, and reel as in the (irassbird. 'The shating on the beast is light, and the bill and feet are black.

\section{LEAST SANDPIPER. PEEP. BUMBLE-BEE. \\ Tringa minutilla.}

Batck of full plumageel birds ashy-gray, mottled with black and brown; throat and sirles, grayish; under bats white; eres hrown: hill and feet, gleenish-slate; length, alout $5 \frac{1}{2}$ inches; extent, 11 inches. This bind hardly 
needs especial description, as its small size is sufficient to distinguish it from the others, although No. 82 is but little larger.

In labits, this species is but little different from the rest of its tribe, running about among the pools of water left hy the recerling tirle, picking up the insects and shell-fish. 'They are exceedingly restless, and seldom in one spot for more than a moment. They breed in the far North, but are so irregular in their movements that they are with us nearly every month in the summer.

I am much in doubt whether to armit these birds in the list, but they are so ciosely associated with others of " like ilk," that I am in a measure obliged to describe them. It would take abont a dozen to make a mouthful, but when that mouthful is olstained, it is one of the sweetest morsels that ever titillated the palate of an epicure. My mouth waters at the thought of "peep-stew," and I can pardon the man who calls then game, though they be not larger than sparrows.

\section{-80. RED-BACKED SANDPIPER. I)UNLIN. FALL-SNIPE. OX-BIRI). \\ Tringa alpina pacifica.}

In the full summer plumage, the back is a reddish-hrown, mottled with black and shaded with grayish tonches; wings, mottled gray and brown, shaded with white; the hearl, neck and breast are ashy, marked with elon- 
gated spots of dirker; belly black, rest of under part white.

The winter plumage is so much different, that they are often esteemed as sepalate birls. They then lack the red back and the black belly. The upper parts are mottled gray, and the under parts nearly white, the Ireast being streakerl with dusky; eyes dark lorown: bill and feet black; length, 8.1 inches ; extent, 15 inches.

This is deserverlly a farorite bird with sportsmen, both from its beantiful plumage. and for its edible qualities. They are on om New England shores about the first of May, and acain during October. They feed on the sandy flats. and in the autumn are easily captureel. any loy leeing able to walk them up or call them down. They inhabit the whole of North America. Hreeding in the Aretics.

There is a slightly smaller hird, which can be only distinguislied ly its size. and disproportionately elevated bill. This is the European Dumlin, a rare risitant to on Atlantic shores.

\section{CURLEW SANDPIPER.}

\section{FERRLOINEOUS SANITPIPER.}

\section{Tringa ferruginea.}

Top of head and back, hright greenishhlack, mottled with a clear reddish; neck and under side, reddish-brown; bill and legs, 
greenish-black; the former long and curver downwards, and the latter long and slender. This bird is a very lare visitor to our A thantic shores, and there are only about fifteen instances of its occurrence here recorded. It is with the hope that more may be reported that this note is inserted. 'The length is about $8 ?$ inches, and the extent about 14 inches, nearly the size of the Dunlin.

\section{SEMI-PALMATED SANDPIPER. PEEP.}

\section{Ereunetes pusillus.}

P'redominating color grayish-brown, formed by the intermingling of hlack in the field of each feather, surrounded hy red and tipped

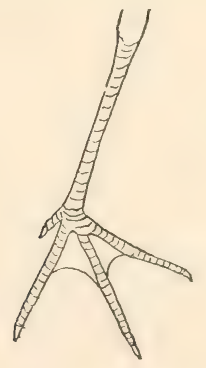

with white; pure white below. In winter and in the young birds the color is grayish, and in both dresses the breast is shaded 
with dark. Length a trifle over 6 inches, extent about 12 inches; eyes dark brown; bill and legs greenish-black.

This bird much resembles the other peep (No. 79), and probably but few sportsmen recognize a difference between them, and for their purposes no distinction is necessary, as their habits are similar.

Many a sportsman, when the larger birds are not flying, makes out his day's sport with these little birds, and when they are wild it will require some patience and craft to secure more than a dozen or so unless they are rery plentiful.

\section{WESTERN SANDPIPER.}

\section{Ereunetes occidentalis.}

This is another case of hair splitting on the part of our ornithologists, and I do not think that orer one in filty of my reader's could distinguish this bird from the last if they lay sicle by sicle, so for all reader's west of the Rockies, for No. 82 read No. 83.

\section{SANDERLING. GRAY-BACKĹ.}

\section{BULL PEEP.}

\section{Calidris arenaria.}

In the summer plumage the lack is mottled with shell-like marking's of black, gray and reddish, formed by each feather having a black centre and a redlish or gray tip. 'This 
marking is a very difficult one to describe in mincientific language, and must be seen to be appreciated. The belly is pure white and the breast mottled. The winter and young plumage lacks the reddish and the breast is shaded with buff. Length 8 inches; extent over 15 inches; eyes brown; bill and feet black.

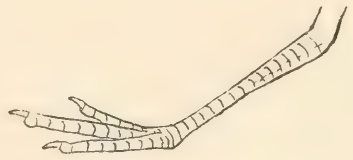

This bird is found at various seasons over the entire continent, and for beauty is surpassed by but few. It passes Massachusetts, going northward, early in May, and returns in July, the adults coming first and the young following in August. They feed upon the sandy beaches and flats almost exclusively, and seem to be in constant motion. They will follow a "breaker" down until they are wading in the rolling surf, and sliurry back to avoid the rush when it returns.

Since the approach of civilization has driven the larger birds away from our shores, more of these birds are shot than formerly, but they are as deserving as the plovers of a place in the game bag. They are a good table bird, and are generally in good condition, especially the young birds in the fall. 


\section{8.). MARBLED GODWIT. MLARLIN.}

\section{Limosa fedoa.}

Predominating color dark hrown, variegated with recklish-brown spots and markingss. The moler parts are of a rusty color, and the markings are finer. The hill is long, curvect

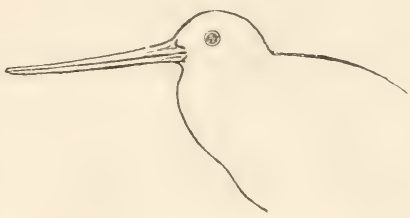

upwards slightly, flesh-colored, with darkbrown tip. Leg' long. llackish. Length 18 inches : extent albout $3: 3$ inches. Eyes brown.

Distinguishing Features. - Rump) and upper sicle of tail barred; lining of wings reckdish; markings on uncler side in short streatis ; bill 4 to $4 \frac{1}{2}$ inches long.

This, one of the largest of our " shore bircls," is not rery common on our Eastern shores, but will be found in goodly numbers south of Cape Inatteras, where they congregate on the marshes; in the interior ther frequent the wet prairies. They are shy birds, but come to decoy well, and, if one is wounded, the other's will often hover over, affording another shot, if the gumner is not in too much of a hurry, and will call them back. 
There is another bird of this family, which is common in Alaska, known as the Whitetailed Godwit, but it so seldom comes within our lange that I do not give it especial mention. It is common in the Old World.

\section{HUDSONIANGODIVIT. SPOT-RUAP.}

\section{Limosa hamastica.}

Predominating color more of a grayish cast than No. 85 ; and the under parts are reddishbrown, barred with dusky and whitish lines. The winter plumage is gray, and under parts grayish-white, with but few markings. Bill like the last-named bird, but much shorter (23. to 31 inches). Legs slate-colored; ejes clarkish-brown. Length 15 inches; extent 27 inches. There are variations of plumage in every combination between the two stages.

Distinguishing Features. - Tail black, tipped with white, and with white base, giving the common name of "Spot-Rump"; lining of wings blackish.

This bircl is somewhat smaller than the Marhled Godwit, but the hahits are very similar. Its range is over the entire continent, south to South America, except west of the Rocky Mountains, but it nowhere seems to be common.

Both these birds are delicate in flavor, and are true game birds. They are often confounded with the curlews, but are readily distinguished, as the bill turns up, and in the other it turns down. 


\section{GREATER YELLOW-LEGS.}

\section{WINTER YELLOW-LEGS. TATTLER}

\section{Totanus melanoleucus.}

Back nearly black, speckled with white. IIead and neck lighter, clue to the white being in the form of streaks; a white line above the eye, and the rump) white, slightly barred. Ender side white, marked with a few lines toward the breast, which is much streaked with gray. Eyes brown. Bill black and long ( $2 \frac{1}{4}$ inches $)$ slightly turned upwads. Leg's long and slender, chrome-yellow in color. Length about 13 inches; extent 2 feet.

'The young plumage is lighter, with fewer' dark markings.

These bircls arrive early from the South, are gone to the far North before summer opens, and on their return linger in the temperate latitudes until the cold weather is fairly upon us.

I know not whether this bird is the more admired as a game hircl, or hated by gumner's for its noisy, rociferous cries when it sees them: many a good shot at plover has been spoiled by one of these lirds setting up its infermal "cu-cu-cu-cu-cu-cu" when they were crawling upon a flock of birds.

Still they are not difficult to secure; are easily called to blind on the edge of the sedge, as their call is not difficult to imitate.

They feed principally upon the small fish which swim about in the little pools left upon 
the flats by the receding tide, and they wade ahout in the shallow water, following its erlge as it recedes and advances, continually keeping up a bolbing motion, as if they kept up the motion so as to strike more quickly when occasion served.

\section{YELLOW-LEGS. LESSER YELLOW-LEGS. \\ Totamus flavipes.}

A miniature counterpart of No. 87 so far as all practical purposes go. Length 11 inches; extent 20 inches; bill 1! inches and straight; the legs are longer in proportion to its size than in No. 87. It is found in the same localities as its larger prototype, and resembles it in habits. In New England, however, it is known as Summer Yellow-legs, since it arrives from the North about the middle of July, and leaves for the South as early as September 15. It is, in autumm, a fat, fairly flavored bird, but is so easily captured that one soon tires of shooting them. They will come again and again to the blind, where lie outstretched a number of their fellows, who have just fallen, and do not seem to mind the showers of lead which are poured into their midst.

I have often wondered where they passed in their spring migration northward, as we seldom see them at that time upon the New 
England coast, and I am inclined to think that they go up the valley of the Mississippi, and spread out after they pass the Canadian range of mountains.

\section{SOLITARY SANDPIPER.}

\section{Totamus solitarius.}

Above, greenish-brown, finely speckled on back and streaked on the head and neck with white; white on the uncler sicle, the sides of the body and neck marked and barred with dusky; tail barred white and black; bill black; feet greenish; eyes brown. The sharles are lighter in the younger birks. Length 8! inches; extent $16 \frac{1}{2}$ inches.

It seems strange that this bird does not figure more in the more popular treatises on game, for it is not an uncommon visitant to all sections of the country. It prefer's, I think, the fresh water, although often fomd feeding from the pools of salt water near the shore. They are very shy, and more or less like the little "Tip-up" "in their behavior, bobbing about on the shores of the shallow streams and ponds. They are very quiet and reserved, and seldom whistle except when started. 


\section{TVILLET. HUMILITY.}

Symphemia semipalmata.

Predominating color of old birds in full plumage dark ashy-gray, varying in shade with the age, and more or less marked with blackish, in interrupted har's; there is also a shading of brown; under side white, with brownish shade, and marked on the breast and sides with black; rump white, and there is a white band on the wings which is very aplarent during flight; eyes brown; bill black; legs bluish. The young plumage is light ashy-gray, under side white, and there are numberless intermediate shades between this stage and full plumage. Length 16 inches; extent 28 inches.

It is claimed that there is a variety,

\section{WESTERN WILLET.}

Symphemia semipalmata inomata.

Which occurs in the district west of the Mississippi. 'The distinguishing' trait is only apparent in full plumaged bircls, except for the slight difference in size, the western bird being a trifle larger, bill longer and slenderer, general tone lighter, and markings not so apparent.

I am not going to quarrel over a shade in color, but whether you find the bird in Kansas or in New Jersey you will find him the 
same shy, suspicious yelper who starts into the air at the first sniff of danger, somding his alarm note, to the end of warning all the bircls within hearing, and discomfiting the gunner. They will, however, come to stool in very fair shape, but when secured are not of much value, as they are tough and of not particularly good flavor. Their haunts and food are much like No. 87.

\section{WANDERING TATLER.}

\section{Heteractitis incanus.}

Predominating color dark gray, uncler side white, sometimes sharted on the throat, and in other phases of plumage streaked and barred with dark. Bill black, length 10 inches, extent about 18 inches. This bird is found along the extreme Pacific coast, and I know nothing about it, and never saw but two specimens.

\section{BARTRAIIAN SANDPIPER. UPLAND PLOVER.}

\section{Bartramia longicauda.}

Predominating color dark brown, each feather being edged with reddish. 'The neck and breast are lighter, which color extends to and upon the head, the top of which is dark 
brown. The breast hears the $V$-shaped mark characteristic of many of our shore hirds. Under parts dirty white. The tail is barred with black, the centre feathers loing darker than the other's. Eyes hazel-brown. Bill yellow below, black above and at tip). Legs greenish-yellow. Length 12 inches. Extent 22 inches.

These birds differ from the majority of its kind in frequenting the high fields, pastures, and prairies, in their search for food, which consists of grasshoppers, crickets, ete.; and it is seldom seen on the shores.

'They are exceedingly variable in their' spring migrations, arriving here (Lat. $42^{\circ} \mathrm{N}$.) from the middle of April anywhere along until the same time in May, and then perhaps there may only a very few appear, where the season before they were plenty. They return in July, and are with us about a month.

Here in the East a more wary bird does not exist, not even barring the grouse, and a good bag of these birds is a rarity.

I have heard that on the Western prairies sportsmen ride them down, and no doubt many a gumner here wishes he could, as he sees a scared flock go "over the hills and far' away" before he can get within range.

They must be stalked, or, if the gumners work in pairs, they may often be driven over.

They are delicious eating, and justly much esteemed. 


\section{BUFF-BREASTED SIANDPIPER.}

\section{Tryngites subruficollis.}

Prevailing color mottled dark-brown with a greenish shade, each feather above being tipped with yellowish. The distinguishing feature, however, is the buff-colored breast and helly, mmarked save for a few spots, where it commences to sharte into the darker color of the bark : this color is deeper in the suring, and in adult birds. Length 8 inches. Extent 16 inches. Eyes brown. Bill dark brown. Legs yellowish-green.

This bird is rare along the Eastern coast, and I think common nowhere. It seems to fly in company with No. T6, and, heing about the same size and of similar habit, I have no doulst is often taken for that bird in the fall migrations.

\subsection{SPOTTED SANIPIPER, TEETER. TIP-UP. OX-EYE.}

Actitis macularia.

Color olive-gray, finely mottled with black. Under sicle white, suotted with black, and there is a white mark orer the eye. Length $7 \frac{1}{2}$ inches. Extent 13 inches. Eyes dark brown. Bill flesh-color, tipped with black. Feet pinkish-white.

I hardly know whether to class this bird as a game bird, but it is hard to say "where 
the chicken ends and where the hen begins." It is as large as a Peep, Nos. 79 and 82, and many a sportsman has made out an otherwise meagre bag with these birds, so why not "Teeters"? They come here in April, anrl stay all summer, feerling and breeding on the shores of the ocean, and, in fact, almost any small pond or river which will afford them food.

The motion of bobbing the tail while moving or standing is as characteristic as is the bobbing of the head indulged in by the Tattlers.

I have never seen these bircls take to the water, but have been told that they will even swim under water for a short distance. They seem to prefer the calm pools to the surfy shores.

I camnot say how they would do for eating, but should think they would be very good if enough could be obtained to make a showing.

\section{LONG-BILLED CURLEW. SICKLE-BILL.}

\section{Numenius longirostris.}

Predominating color reddish-brown, barred or spotted with darker. Under side cinnamon-brown, ummarked save for a few faint streaks of clarker. Length about 2 feet. Extent over 3 feet. Eyes dark brown. Bill black, 
the under side yellowish, and rery long, much curved downward. This is a distinguishing feature of the birl, often measuring 6 or 8 inches in length. Leg's hluish. Weight averages about 30 ozs.

This is one of the lingest game birds which visit our shores, and is accordingly much prized by sportsmen, although as a table bird

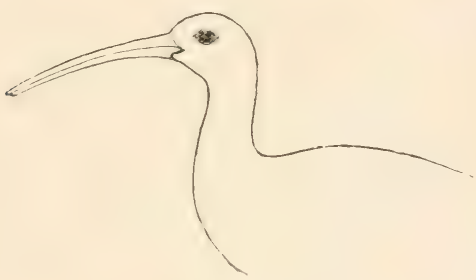

it is far inferior to the Plovers. They will stand a heavy dose of lead without coming down, and as they fly high, are not always captured when seen.

When they were more common, they were easily "whistled" down, but they have become rare on our shores, although not uncommon in the Southern States in winter.

They feed on the flat sand-bar's upon crabs and other small crustaceans, which impart to their flesh something of their characteristic flavor. 


\section{HUDSONIAN CURLEW. JACK-CURLEW.}

Numenius hudsonicus.

Very similar in general appearance to No. 96 , but smaller and lighter in color. More gray in general tone than reddish, and whitish unclemeath. Length 18 inches. Extent 32 inches. Bill black, and much shorter in proportion than that of No. 96, seldom being over $3 !$ inches long, lut with the decided downward curve peculiar to the family.

This is our common Curlew, although the Dough-bird, No. 98, is most often seen in the market, being more prized for its flesh; the "Jack" being ranker, more like its larger relative, No. 96.

The flight of any of the Curlews is not very lapid, but is strong and well sustained.

\section{ESKIMO CLRLEW. DOUGII-BIRD.}

\section{Numenius borealis.}

Very similar in appearance to the other Curlews, but smaller than either of the others, and of a generally richer tone of color than No. 97, from which it varies in having $\mathrm{V}$ shaped marks on the loreast instead of short bar's; but the size of the lird is the best point of difference. Length about 13 inches. Extent 28 inches. Bill blackish, about $2 \frac{1}{4}$ 
inches long, and more slender than in the others of the family. Leg's dark blue, with a greenish shade. Eyes dark brown.

'This bird is found farther from the shore than the other curlews, as it loves the dry marshes, and the fields and pastures along the seashore, where it can find its farorite food of grasshopper's and crickets, and the higher land berries, when these are to be found, and which impart to their flesh the more pleasing flaror than is characteristic of the other ('urlews, and which renders them of more value as a table bird, hence commanding a higher price in the market.

There has been much dehate over the orthography of its common name, Dousfl or Doelircl. I have given preference to the former, merely from the individual opinion, backed by that of local New England market g'mmers, based on the description of its fat conclition, which conveys the idea of a lump of dough.

\section{BLACK-BELLIED PLOVER. BEETLE-HEAD.}

\section{Charadrius squatarola.}

In full breecling plumage, the upper part of the head and neck is nearly white, with faint gray markings; the back is nearly black, mottled with white and lorown. 'Tail barred with black and white. The sides of the head, throat, and under side of body, is deep black, 
shading into white at the base of the tail. Feet and bill black. In the immature and winter plumage all this is changed, however, and the bird loses nearly all its black color; the back becoming mottled brown and white, the breast nearly white, with a few darker markings; even the legs and bill assuming a lighter tone; and these birds shot at the different seasons of the year assume all the various grades between these two plumages.

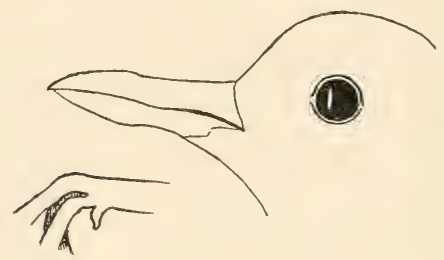

These birds are often confounded, more particularly in the gray phase, with No. 100, but they are easily distinguished by the presence of the minute hind toe, which is lacking in the Golden Plover (see No. 100).

Extent of wings 25 inches. Length of bird 11: inches. Eyes brown.

This bird is found in nearly every quarter of the globe, and migrates North and South with the changes of the season. The flocks frequent the beaches at low water, and, when the flats are covered, they retire to the marshes, there to await the fall of the tide to 
uncover their favorite food of small shell-fish. although they eat the insects of the higher beaches.

They are shot from blinds at high water, over decors, and whistled down, as they fly from the flats as these are corered by the Howing ticle. But the gumner must be a goou "caller," or his bag will hang light, for an old "beetle-hear" is as crafty as a fox, and an experienced gunner will not even use decoys on the high beaches, as the old bircls will often not come down to them, but he will pick out a spot which was oceupied, on a former ticle, by the bircls, olig a hole in the sand, cover it with boards and sand, learing opening's to shoot from and linock them over as they come up.

On the flats a sink-box is built on a bar, either natural or artificial, and the birch will approach, as it is monerered before the surrounding flats are bare.

I know of no bircl which is a more universal favorite with sportsmen, as it requires the greatest skill for its capture, and affording, as it cloes, a fitting reward for the troulble undertaken.

The flesh is delicate, and the birds generally plump. 


\section{AMERICAN GOLDEN PLOVER.}

\section{GREEN-BACK. BULL-HEAD.}

\section{Charadrius dominicus.}

Prevailing color brownish-black, in the old birds, marked on the back with numerous round spots of golden yellow, under parts black. This plumage changes in the autumn to a duller shade on the back, and the black disappears from the breast. which is now dirty white, irregularly blotehed with dark brown spots which disappear in the winter, when both old and young birds are dark brown above; the light markings are larger than in the spring, giving a generally lighter tone.

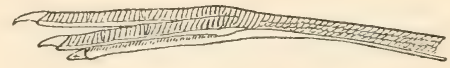

The under parts are now dull white, with grayish spots, which wholly disappear towards the base of the tail. Length about 10 inches. Extent about 22 inches, being a little smaller than No. 99. Feet and bill dark bluish. Eyes dark brown.

This bird is often confounded with the Beetle-head (No. 99), but is easily distinguished by the absence of the little hind toe. There are many other points of difference, as may be seen by comparison of these notes, but this is always constant and easily apparent. 
It shares with its relative (No. 99) the esteem of sportsmen, and rivals it in its delicacy as a table bird.

It frequents the high beaches and neighboring uplands, and in habits and food much resembles No. 98, with which it much associates.

These birds are shot on their flights, from holes lug in the ground and used as a corer for the gumner.

\section{KILLDEER.}

Egialitis vocifera.

Top of head and upper parts dark grayishbrown. Forehead, stripe orer the eye, and under parts white, with two black bands on the throat. Rump bright chestnut. Wings and tail variegated with black, brown and white. Length 10 inches. Extent 20 inches. Legs yellowish-gray. The immature plumage is similar but not as bright.

They frequent the jastures and marshes and the border's of muddy ponds, and are rery abundant in the W'est. They were formerly very plentiful on our Easter'n shores, hut of late are seldom seen. The only time that any number have lately been seen East, was in November of 1888, when thousands were driven upon our shores by the great gale of November 25, and was then announced by me in the Boston Transcript of December 12. It was thought by some that these birds were now to return to their old haunts, but 
they have never been seen since in any numbers.

In the WVest, where they are abundant, they are easily found, as their vociferous cries of "kill-cleer, kill-deer," are constantly uttered, and they are not difficult to approach.

\section{SEMI-PALMATED PLOVER. RING-NECK.}

Agialitis semipalmata.

Upper parts clark gray. Under parts white. A broad black band encircles the neck, bordered in front with white, and a white stripe on forehead surrounded by black. Length 7 inches. Extent 15 inches. Bill yellow, black tipued. Legs flesh-color. Eyelids orange. Toes partly webbed.

I presume that I may be criticized for including this among game birds, but it affords good sport when larger birds are scarce, and is good eating.

They frequent the flats and beaches, going to the higher beaches to roost.

\section{PIPING PLOVER.}

AEgialitis meloda.

Pale and ashy-gray above. Forehead, sides of head, under side and ring around neck white. There is a black bar across the top of head between the eyes, and another which 
more or less encircles the neck. (There is a variety in the Wrest, occasionally found on the Atlantic coast, which has the black band on the neck completely encircling it, and this has been named A.m. cirememcinctus, lut it (liffer's in no other way.) Bill yellow, black at tip. Legs orange-yellow. A colored ring around the eye. Length about bi inches. Extent about 14 inches, being a trifle smaller than No. 102.

They are rery pretty bircls to shoot, but, if wounded, will run like a witch, and are then a good test of marksmanship.

\section{SNOTWY PLOVER.}

\section{Egialitis nivosa.}

A little lighter in color than No. 103, ancl with a reddish tinge on the tol) of the head, which is nearly surromeled by a band of black. There is also a patch of black on either sicle of the neck, hut it makes no attempt to encircle it as in No. 103, and there is no black band on breast as in No. 10j. Bill black and slender. Legs black. Length 7 inches. Extent about 14 inclies. Eyes and eyelids dark brown.

This bird is found upon the Wrestern shores and sometimes about the Gulf of Mexico and the salt lands of the interior. I know nothing of its habits, but am informed that it resembles No. 102. 


\section{WILSON'S PLOVER.}

Egialitis wilsonia.

This bird resembles No. $10 t$ very elosely, lout differ's in having a black bancl on the neck which does not extend over upon the back. The bill is very stout and large, and the legs are flesh-colored. Slightly larger than No. 10t; that is, a small specimen of this species would be about the same size as a large specimen of the other.

It is found quite commonly on the shores of the South Atlantic and Gulf States.

\section{MOUNTAIN PLOVER.}

\section{Egialitis montana.}

Prevailing color grayish-brown. Entirely white beneath. Forehead white, bordered with black. In winter, or in the young birds, the black marks on the head are not present, and the plumage has a rusty tinge. Bill black and slender. Legs pale brown. Length about 10 inches. Extent 18 inches. Eyes dark brown.

These birds inhabit the high prairies, and seldom are found near marshy lands. 'They feed upon insects. 


\section{TURNSTONE. CHICKEN PLOVER. CALICO-BACK.}

\section{Arenaria interpres.}

The arlult male in breeding plumage is dressed like a harlequin, the lack being blotehed with black, white, brown and chestnut. The under side is jure white, broken by a broad patch of black upon the breast. The lower part of the back is white. with a black patch on the rump), ancl the tail is black bordered with white. The wings also, hear a large white patch. The head is mottled black, hrown and white with a broad black patch on either side extending down to the sides of the neck and comnecting with the breast patch. The color's of the female atre similar but the chestmut color is replatced with hown, and the general effect not so bright. Immature and winter plumage mostly lrown and gray. The bright color's of the hack are generally a clistinguishing feature sufficient for recognition. The bill is black. Feet orange. Eyesblack. Length 9 inches. Extent 18 inches. There is a variety on the Pacific coast in which the characteristic red color is replaced by hlack.

These birds are found in nearly all quarters of the globe, and generally in small flocks of three to twelve, feeding upon the marine animals which it collects upon the shores by turning over the small stones, whence its name. Their farorite haunts seem to be 
the pebbly beaches, but they are often taken upon the marshes and upon the low sand flats and bars.

They are one of the most conspicuous shore birds, and once seen will be easily recognized. Their flight is very rapid, and, while on the wing they incessantly repeat their short, sharp, whistling note, which is especially hard to imitate, but they are not very shy, and will come down to almost any of the shore-bird decoys. I never tried to eat them but once, and was not favorably struck by their flavor, which resembles that of fish oil.

\section{AMERICAN OYSTER CATCIIER.}

\section{Homatopus palliatus.}

Predominant color smoky-brown, with black head and neck. Under parts white, and the wing bears a conspicuous white patch. (There is a variety on the Pacific coast, $H$. niger, which is entirely black.) Bill 3 to 4 inches long, varying in every specimen, and often thin on the end and bent to one side, from its constant use in opening the shells of molluskis; coral red, yellow tipped. Feet and legs livid. Eyes and eyelids red. Length 18 to 21 inches. Extent 30 to 36 inches. Said to be non-edible, although I can see no reason why it should be so, as they feed almost entirely on shell-fish. 
E. H. Forbush, State Ornithologist of Massachusetts, tells me that this bird is very good eating, if quickly cleaned. And it is lrobable that many of those hircls, which are ordinarily not esteemed fit for food, if drawn as soon as killed, and soatied a little while in water, would be found rery palatable. 


\section{LAND BIRDS.}

\section{BOBWHITE. QUAIL. VIRGINIA PAR'TRIDGE. \\ Colinus virginianus.}

Predominating eolor redclish-brown, mottled and streaked with black and darker brown, lighter on the under parts. The male has the forehead, line over the eye, and throat white, bordered with black, which color is replaced in the female by buff. Bill dull black. Legs gray. Eyes rlark brown. Length $9 \frac{1}{2}$ to $10 \frac{1}{2}$ inches. Extent $14 \frac{1}{2}$ to $15 \frac{1}{2}$ inches. Weight about 7 ozs.

There are two so-called varieties of this bird. Its range extends from Massachusetts to Texas and westward throughout the eastern United States. The bird described above is the one from the northern section. As we follow the species southward it gradually becomes smaller and darker colored on the eastern coast, producing the Florida variety (Cotims viryiniams. floridamus), and in the extreme southwest, becomes more gray, which variety is called $C$.v.texamus, but they are all practically bobwhite just the same. 
There is no game hird more miversally known and admired, for to the sportsman he affords a tempting mark as he flushes before the dogs, and whim's off through the sharp air of autumn, his little hody blencling closely with the glay-lorown of the fatling foliage, to drop, after a short flight, in the first conlvenient covert, where he is soon located by the lieen scent of the $\log$, to fall perhaps, at the gun's report. The bollwhite frequents the semi-open fields and prastures which afford him cover in the short lorush and food in the open. At night, clustered together, the flock passes the sleeping hours, and during bat weather, in these same corer's, and often in serere storms of sleet, they are frozen under by the acemulation of the frozen snow, to miserably perish. I know of nome of our game hirds whose very existence is so constantly in danger; a prey to the prowling fox ly night. and chased and hadassed hy birels of jurey by day, added to the other evilis of destruction. It is a wise provision of Proviclence that they are so prolific, a single hen bringing up ealch year two litters of ten to fourteen chichis. 'They feed upon insects and the seeds of weeds, and no better ally can the farmer have for the protection of lis crops than a few coveys of quail in his fields. 


\section{MOUNTAIN PARTRIDGE. PLUMED QUAIL. MOLNTAIN QUAIL. Oreortyx pictus.}

I shall not here attempt to separate the two varieties now laid down in the list, as they are practically the same bircl. Predominating color olive-brown, with a coppery lustre.

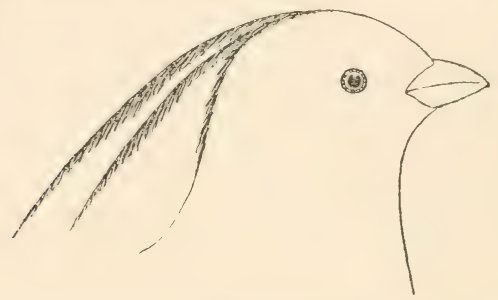

Breast slaty-blue, shading into the olive at the back, and finely marked with black. Throat and belly chestnut. There is a black line, bordered above with white, on either side the neck, and the sides are banded with broad bars of white and black. The distinguishing feature of this bird is the two black arrowy plumes on the crown of the hearl, which are 3 to $t$ inches long in the male and much shorter in the female. Bill and feet brown. Length 12 inches. Extent 17 inches.

This beautiful bird is an inhabitant of the mountainous regions of the northwest, haunting the underbrush. They are not fast flyers, and will often try to skulk off when approached, which tactics are extremely suited 
to the thick corer's which they frequent. The opunions of my rarious conrespondents differ as whether they will lie well to the dog, some say yes and some no, but all agree that they furnish fine sport.

\section{SCALED PARTRIDGE. BLUE QUAIL. \\ Callipepla squamata.}

Predominating color leaden-blue, diarker on the batck. 'The distinctive feature of this lind is the peculiar shell-like marking of the neck and breast, produced by the black edgings of the feather's. The crest is short, and composed of several feather's, hut is not so prominent as in others of the crested quails. There is a lange patch of recklish-hrowin on the helly, which in some sleceimens sharles into chestnut, giving rise to a rariety linown as custanoydastris. This latter variety inhalyits the lower lands; and the main species. the tablelands of Texas, New Mexico, and Arizona. Length 11 inches. Extent 15 inches, being a little smaller than No. 110.

\section{CALIFORNIA PARTRIDGE. VALLEY QUAIL. (var.)}

Callipepla californica.

Predominating color ashy, shaded with olive-brown. The breast is bluish-slate; below this, on the under side, is a patch of 
chestnut, sharling into tawny brown toward the edges, with the tips of the feather's exlged with black. 'The head of the male is marked with a white line over the eye and a white forehead. The head is sumomnted with a crest of 6 to 10 black feathers, curved forward.

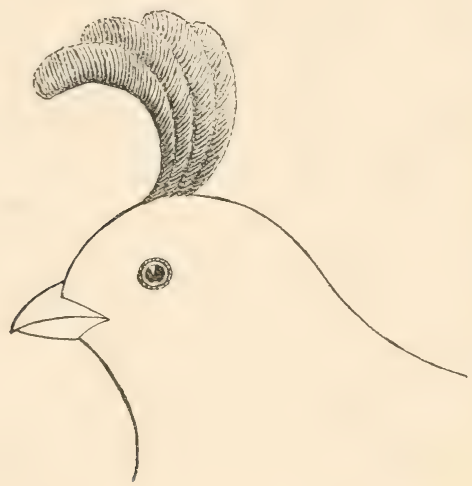

The female has not the black throat nor the head markings, and the erest is smaller.

Length 11 inches. Extent ahout 16 inches. It inhabits California and Oregon east to the Colorado River.

Much has been written concerning the comparative merits, as a game bird, of this, as compared with our eastern quail, and, from what I can gather, I am inclined to think that bobwhite is on top. The Californian does not lie well to the dog until they 
have been badly scared, and then they go like a "l)lue streali." Howerer, they are a good tible lird, and afford considerable sport, since they are quite numerous. They halit the thick cover of chaparral and weerts.

\section{GAMBEL'S PAR'TRIDGE. \\ Callipepla gambeli.}

This hired is own cousin to the last (No. 112), (liffering in having a black forehead instearl of white; no white line beneath the eye; back of head chestnut instead of smokybrown; sides chestmut with white stripes; and the middle of the helly jet-l)lack instead of chestnut. Otherwise in appearance and habits like its Californian relative.

\section{DLSKT GROUSE. BLUE GROLSE.}

\section{Dendragapus obscurus.}

Preclominating color very dark brown, finely marbled with grar, shacling into bluishgray on the under sicles. Cheeks black. Tail rounder, of 18 to 20 feathers, dark brown like back, tipped with a band of gray. Bill hlack. Eyes golden-brown, with a comb above. Length 20 to 24 inches. Extent about 30 inches. Weight 3 to 4 lbs.

The female is of a lighter shade than the above, and a little smaller than the male. 
This great bird is a native of the Rocky Momntains, the darker varieties known as Richardson's and Stooty Grouse occulying the northern limits.

From all that I can gather from my correspondents in relation to its haloits, it seems to be a somewhat stupid, lazy bird, not easily flushed, but a strong, rapicl flyer, when startled; frequenting the high coniferous trees luring the most of the year. From all accounts, it affords but comparatively poor sport, aside from its great size and abundance, as it must be shot while sitting, and it appear's to have the ability to so adjust itself upon the limbs as to almost completely hide from the gaze of the observer. One correspondent tells of killing six loy throwing stones at them, and another of shooting them out of the high trees 100 feet from the ground. In some places they are shot when flushed, and, in the other instances, they should afford good sport with a rifle.

\section{CANADA GROUSE. \\ SPRUCE PARTRIDGE.}

\section{Dendragapus canadensis.}

Prevailing color of adult male, black, lighter on the back, waved and spotted with white and tawny. Tail of 14 to 18 feathers tipped with brown. The female and immature male are somewhat like the above on the back, but not so dark, and the under side is 
variegated white and tamy, wared with blackish. There is a red coml orer the ere. Length about 16 inches. Extent 22 inches. There is a slightly differing variety in the Northwest. The habitat of this bird is the northern part of the continent, south into the northern border of the United States.

Althongh a rery handsome bird, it is little sought for by sjortsmen, since its flesh, though sometimes not had, is generally so impregnated with the flavor of the spruce buds ryon which it feerls, as to rencler it utterly uneatable. Ind it affords but little sport, for it is so stupid as to allow the approach of man within a few yarks, and is even taken with a slip-noose on the end of a pole.

I saw three of these hirds breeding in captivity at Kentrille, N. S.. and I believe that their owner. Mr. Bishop, enjoys the unique honor of heing the only lerinin who has succeeded in their domestication.

\section{RUFFED GROUSE. PARTRIDGE. PHEASANT.}

Bonasa umbellus.

Prevailing color variegated grayish-brown (in some specimens shating into a rectdishbrown with bronze lustre). Whitish below, barred with brown.

The male has a ruftle of glossy black feathers about the sicles of the neck, which in 
the female is smaller and of a brown color. 'The tail, normally of 18 feather's, is rouncled, and bear's a band of black near the tip. There are three varieties, due to climatic agencies, and they grade into each other insensibly.

Bill and legs light brown. Eyes brown. Length 16 to 20 inches. Extent 23 to 25 inches. Weight $1 \frac{1}{4}$ to 2 lbs. I have heard of "King-partridges" as large as a turkey, but never saw one: and a 2-pound bird is a big one.

The bircls inhabit the greater portion of civilized North America, except the Southwest, and, except where seldom hunted, are, taken all in all, the most noble game bird of which this country boasts. I have seen these birds flush from the ground and settle upon a tree not over 200 feet away, and eye me as curiously as if I was a clime musemm freak, and I have been threatened with condign punishment by correspondents in the North and West for the above remark. But if any of these friends will have a try at these birds here in our Eastern States, I will wager that they change their minds. The sportsman who brings in a good bag of these birds here is worthy of a place in the front ranks of the guild. It is warier, and filled fuller of strategy, pound for pound, than any living bird on our soil.

Like nearly all gallinaceous birds, the male has the habit of strutting during the sexual period, which is accompanied by various 
sounds calculated to attract the female and exalt it in her estimation; and, in the case of the ruffed grouse, the act is termed "drumming." At this time they seem to be oblivious of all else, but he is a good man who can surprise the bird even then.

Any discussion of the habits of the bird would seem superfluous; volumes have been written on the sulject, and more will follow just as long as man can walk the fields.

\section{WILLOW P'TARMIGAN.}

\section{Lagopus lagopus.}

There is no American hird which exhibits such peculiarities of plumage as to the Ptarmigans. For they are constantly moulting, and there are no two weeks in the year when a bird would correspond to any accurate description ; and no bird exhibits such a complete change, for even the horny coverings of the bill and toes are cast off with the feathers, and the plumage varies in every gradation of color, from the beautifully mottled summer coat of blacks and browns to the nearly uniform white of winter.

In the full spring breeding plumage, the predominant color is rich hrown, inclined to tawny, mottled and harred with black and white; the most of the wings and the alotomen white. The female is similar, but more tavny, including the abdomen. The legs are feathered to the toes; the winter plumage is 
white, except that the tail is black. Ornithologists have lately divided this species into two. The principal point of difference being that the original species has the quills of the outer wing feathers white, and the variety (alleni) black. Bill black and stout. Eyes hazel. Lengtl about 17 inches. Extent about 24 inches.

This bird takes the place in the North of the grouse in the South, and they afford as fine sport in their haunts as do their relatives of the South. They are strong flyers, and lie well to the dog.

They are found on the marshy lands, and their number's, in those sections where they have not been too much molested, is something incredible, their cry of "Go back, go back" resounding from every quarter when disturbed.

\section{ROCK PTARMIGAN.}

Lagopus rupestris.

This bird much resembles the foregoing, but is smaller, and the color is more of a brownish-yellow, and in the winter there is a black stripe on each side of the head, which is not possessed by No. 117. The bill is more slender. Length $1 \pm$ to 15 inches. Extent about 22 inches.

There are three varieties of this species described by the later ornithologists, and another bird from Newfoundland (L. velchi) 
which has been considered sufficiently distinct to form a new species. But they are sufficiently similar to be considered as one and the same, so far as our purpose goes, and in view of the numerous variations of inclivichul plumage, the subdivision is extremely problematical, except to the expert.

\section{WIITE-TAILED P'TARMIGAN.}

Lagopus leucumus.

Habitat - Rocky Mountains. Size and appearance similar to No. 118; but the tail remains white throughout the year, and the wings and abdomen are of this color in the summer plumage. Found on the mountain ranges, from the timber-line upward, coming lower down in the winter, as the other forms come southward at the same time.

\section{PRAIRIE HEN. PINNATED GROUSE.}

Tympanuchus americanus.

Predominant color grayish-brown, heavily barred with black. Head buffy, undersicle dirty white, barred with brown. "Top of head and stripe on each sicle, black. Tail dusky, tipped with white. The most peculiar feature of this bird is the black tuft of feather's 
which adorns the neck on either side, beneath which is a large, bare patch of yellow skin which in the breeding season the male distends. The female is very similar, but the neck tufts are shorter. Length 17 to 18 inches. Extent 28 to 29 inches and over. Eyes brown. Bill brown. Feet yellowish.

This bird, while not for a moment to be classed with the ruffed grouse, is still a great favorite with sportsmen. Their flight is not so rapid as that bird, but more protracted and unaccompanied by the disconcerting whir-r-1 of the other, although they can raise up quite a racket when suddenly disturbed.

Their flesh is dark, and does not compare favorably with that of the ruffed grouse, but being more plentiful they occupy a favorite place in the market.

Their habitat is the open prairie, seldom visiting the timber. In former days, this bird, or a representative of the family (the heatlhen), was not uncommon on our Eastern plains, but they have gradually dwindled away, until only one colony now exists, upon the island of Martha's Vineyard. And such is the greed for gore and gain, that were it not for the strenuous efforts of a few farsighted men, who can see more than a foot beyond their moses, these birds, too, would have long since gone the way of the Great Auk and the Labrador Duck. I cannot speak in too strong words of contempt of the action of those, who, even now in spite of the pro- 
tecting laws, seek to remore the last of this race which once was found commonly distributed over our land.

There is a variety of the prairie hen which is foumd in the South, smaller and lighter in color. 'The characteristic bar's are narrower, and brown or grayish, rather than black. The length is 15 to 17 inches, and the extent 27 inches. Otherwise it differ's, neither in habits nor appearance, from the usual form as commonly seen. In fact, it is merely a form, which, by reason of its surroundings, has become changed from the original tyle, and being isolated from it, has in progress of time become perpetuated.

\section{SIIARP-TAILED GROLSE.}

\section{Pediocates phasianellus.}

This is the northwestern representative of the prairie-chicken, and is somewhat similar in habits, but not at all in appearance. The predominant color is ashy-gray, marked with irregular spots and bars of black, white and tawny-brown. 'The underside is nearly white, and marked with $\mathrm{U}^{\mathrm{T}}$-shaped spots of brown. The throat is light buff color, and there is quite a pronounced crest on the top of the head. Unlike the preceding species of grouse, this bird has no neck ornaments, but a close examination will disclose there the characteristic bare spots, which are seen during the breeding season. Two varieties have been 
made of this species. The Northern form is darker, with but few brown markings, and the spots on the breast are $\mathrm{V}$-shaped; and, curiously enough, the lighter and browner form, of the extreme South, also exhilits this $V$-shaped mark, although separated from the other by the common type. A distinctive feature of this bircl is the tail, which is triangular in shape, when in a natural position, the middle tail feathers being about four times as long as the outer. From this arises the name. Bill and feet brown. Eyes brown. The legs are feathered to the feet. Length 18 to 20 inches. Extent 25 to 30 inches.

As compared to No. 120, this bird ranks high as a game bird. Its flight is strong, swift and clirect, and its flesh much superior to the other bird.

An attempt, undoubtedly so far successful, is being made to introduce this bird to our castern fields. While it will probably nerer take the place of our ruffed grouse in the estimation of our sportsmen, any adclition to our feathered game will be welcomed, to afford a bag to those who desire to hunt over our fields, now rapiclly being depleted of game birds.

\section{SAGE GROUSE. SAGE COCK.}

\section{Centrocercus urophasianus.}

The monarch, so far as size is concerned, of the grouse, but, alas! there his dominion 
ceases. Many times the tyro sportsman has been sadly left, when he has thought himself possessed of a good dimmer in an old sage cock. A correspondent writes: "I never attempted but once to eat an old bird, and I shall never try again, I would rather eat a broiled plug of tolaceo; but for a fine morsel, commend me to a young bird in the summer. I could not believe such a transition possible; they heat a woodcock - all hollow " at that time." The color is gray, variegated with black, brown and buff on the back, and dirty white below, and the neck has two bunches of hair-lilie feathers, bencath which is the air sac which can be extencled to enormous proportions. The tail is long and composed of twenty stiff and narrow feathers. The full-grown cock is over 2 feet long, while the hen will seldom reach this measure. The extent is about 3 feet, with about the same proportion for the female bircl. Weight 3 to 5 lbs.

When this great bircl gets up in front of the gumner, he is apt, if not accustomed to the bird, to have a serere attack of ague, although one friend tells about kicking them out of the sage-brush. The flight is strong, and when a wild bird is started, don't try to follow him, he may go a mile. 


\section{WILD TURKEY.}

Meleagris gallopavo.

There are two species of this bird in North America, else I should deem it umecessary to give any description. The wild turkey proper was formerly distributed generally over Eastern North America, but it is now found only in those portions but little visited by man, and not even there are they, by any means, common. The general color of this bird is black, with a coppery lustre, each feather being margined with velvety black. The tail feather's are dark chestnut, with numerous bar's of black. This same color characterizes the sides and coverts. The southern species, which is the original of the domesticated turkey, has the feathers at base of tail, on the back, chestnut, tipped with whitish, and the tips of the tail feather's are whitish. In both species the head is bare of feathers, colored blue, with reddish excrescences. The forehead is fumished with a depending, fleshy, cone-shaped process, which is erected in moments of excitement. There is also a hairy tuft upon the breast. Length 3 to \pm feet. Extent $t_{2}^{\frac{1}{2}}$ to 5 feet and over. Eyes brown. Bill brown. Legs dark and reddishpurple.

This monarch of game birch, like similar representatives of liuman bipeds, is rapiclly disappearing before the march of civilization 
and progress. Once common in New England, it is there extinct; and this noble bird must now be followed by sportsmen to the forest fistnesses of the South and Southwest. i few still exist in the Allegheny range, but they are seldom taken.

A successful turkey hunter is the embocliment of all that appertains to woodcraft ; and he who can call a gobbler within range is worthy of a place in the front ranks of the sportsman fraternity.

Their food is a mixture of nuts, seeds, and insects, and their flesh is as much esteemed for the table as that of the domestic bircl.

\section{PASSENGER PIGEON.}

\section{Ectopistes migratorius.}

Color blue above, recldish-brown heneath, becoming lighter toward the tail, which, composed of 12 feathers, is brown in the middle and blue on the sides. These blue feathers, when pulled apart, show a wel of white on the imner sides. The neck is beantifully glosised with a golden-violet. Bill black. Legs hluish. Feet red. Eyes red. Length 16 to 17 inches. Extent about 2 feet.

This is the bird popularly linown as the wild pigeon. It was in former years commonly distributed over the entire country, passing North and South during their migrations, in immense numbers. Even now, scattering birds are seen in the East, but we 
must now go to the IV est to find the flocks, and, there even, their number's are greatly lessened.

It could hardly be called sport to hunt them when they were common, for a shot fired into the midst of a flock would bring down numbers of them, but they are now somewhat followed as game. They are fine eating; and it takes a good shot to secure a single bird, as their powers of flight and its velocity are wonderful. They migrate in flocks, sometimes of immense size, but although they remain in colonies, they breed in single pairs. 


\section{N D EX.}

I'IGE

Arocet . . . . . . . . . . . . . . . . . . .

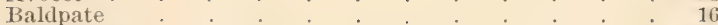

Beetle-hear . . . . . . . . . . . . . . . . . . . . . . . .

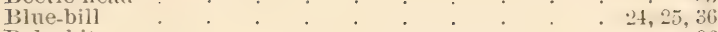

Bobwhite . . . . . . . . . . . 96

Brant . . 41

Black . . . . . . . . . . . . 41

Broad-bill

$: 3$

$19,24,3 t$

Brown-back . . . . . . .

Bufle-head "s

Bull-head . . . . . . . . . . . . . . . . . . . 88

Bumble-bee . . . . . . . . . . . . . 67

Butter-ball . . . . . . . . . . . . . . . . . 36

Butter-bill . . . . . . . . . . . . . . . . . . . . . . . . .

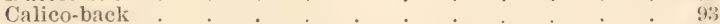

Cock-a-twee . . . . . . . . . . . . . . 29

Coot, American . . . . . . . . . . . 53

Bull . . . . . . . . . . . . . . . . .

Gray . . . . . . . 34

Sea . . . . . . . . . . . . . 33

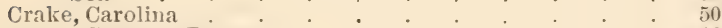

Crane, Commou Browu . . . . . . . . . . . . . 46

Little Brown . . . . . . . . . . . . . 46

Sandhill . . . . . . . . 46

Whooping . . . . . . . . . . . . . . 45

Curlew, Eskimo . . . . . . . . . . . 84

Hudsonian . . . . 84

.Jack . . . . . 84

Dipper

Long-billed

Diver, Great Northeru

Dough-bird . . . . St

Dowitcher . . . . . $66^{2}$

Dunlin . . . . . . 6

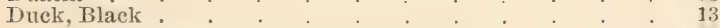

Canvas back . . . . . . . . . 2:3

Dusky . . . . . . . . . . . 13

Eider : . : . : . $\quad 32,33$

Florida . . . . : . . . 14

Golden-eye . . . . . . . . 26

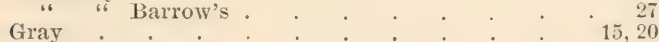

Harlequin : $: \quad: \quad: \quad: \quad \cdot \quad \cdot 30$

Labrador . . . . . . . . 31

Long-tail . . . . . . . . . 29

IIottled $\quad \vdots \quad \vdots \quad \vdots \quad \vdots \quad \vdots 14$ 
Duck, Painted

IAG E

Pintail $\div \quad \div \quad \div \quad \div \quad \div \quad \div$

Pied

Raft

Red-head

Ring-necked .

Ruddy

Scaup

Sea

Shoveller

Spirit

Summer

Tree

IVild

Gadwall

Wood

Gallinule, Purple. Florida

Garrot

Godwit, Marbled

Hudsonian

Goosander

Goose. Blue

Brant

Cackling

Canada .

Emperor

Hutchins's

Laugling

Painted

Ross's

Snow

White-cheeked

White-fronted

Grass-bird

Gray-back

Green-back

Green-head

Grouse, Blue

Canada

Dusky

Pimmated

Richardson's

Ruffed

Sage

Sharp-tailed

Humility

Sooty

Killdeer

Knot

Long Shanks

Lo011

Black-throated

Pacific

Lord and Lady

Red-throated

Mallard

Marlin 
Marsh-hen, Fresh-water . . . . . . . . 47

Salt-water .47

Meadow-lien . . . . . . 53

Merganser, American .

Hooded. 10

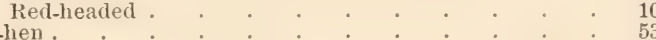

Mud-hen.: : :

Old-Squaw . . . . . . . . . . . 29

Ox-bird . . . . . 68

Ox-eye . . . . . . . . . 81

Oyster Catcher . . . . . . . . 94

Partridge 103

California : $: \quad \therefore \quad \div \quad \div \quad \div 99$

Gambel's . . . . . . . . . 101

Mountain . . . . . . . . . 98

Scaled. . . . . . . . . . . 99

Spruce . . . . 102

Peep

Virginia . . . . . . . . . 96

67,70

Buli : $\quad \therefore \quad \div \quad \div \quad \div \quad \div$

Phalarope, Northern . . . . . . . . 56

Red . . . . . . . 55

Wilson's . . . . . . . . 56

Pheasant . . . . . . 103

Pigeon, Passenger . . . . . . . . . . 113

Plover, Black-bellied . . . . . . . . 85

Chicken . . . . . . . . . 93

Golden . . . . . . . $\quad .88$

Killdeer : $\div 89$

Mountain . . . . . . . . . 92

Piping . . . . . . . . . . . . 90

Red-breast . . . . . . . . 63

Semi-palmated . . . . . . . . . . 90

Snowy . . . . . . . . 91

Upland . . . . . . . . . . . 79

Prarile Hen . . . . . . . . . . . 107

Ptarmigan, Rock . . . . . . . . . . 106 Quail

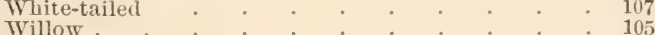

Gambel's $\cdot 101$

Nountain 998

Plumed . . . . . . . . . . 98

Rail, Black * * * * * 95

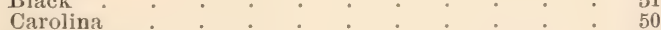

Clapper . . . . . . . . . . . 47

King . . . . . . . . . . 47

Red-breast . . . . . . . . 47

Sora . . . . . . . 50

Virginia . . . . . . . . . . 49

Ring-neck

Sage Cock : $: \quad: \quad: \quad \cdot 110$ 
Sandpiper, Baird's

Bartramian. . . . . .

Buff-breasted . . . . $\quad \$ 1$

Curlew . . . 69

Ferrugineous . . . . . . . . 69

Least . . . . . . . 67

Pectoral . . . . . 6.5

Purple . . . . . . . . . . 65

Red-backed . . . . . . . 68

Semi-palmated . 70

Solitary . . . . . . . . . 57

Spotted........ . 81

Stilt . . . . . . 63

Western $. \quad . \quad . \quad . \quad 71$

Sawbill

White-rumped . . . . . . . . . . 66

Scoter, American

Surf 35

White-wing . . . . . . . . . 34

Sheldrake, Pond . . . . . . . . . . . . . 9

Sickle-bill . . . . . . . . . . . 52

Skunk-head . . . . . . . . . . . 3 .

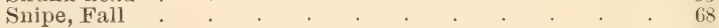

Jack . . . 65

Red-breasted . . . . . . . . . . 62

Robin . . . . . . . . 62,63

Wilson's . . . . . . . . . . 61

Sora.$\quad 50$

Sou-southerly . . . . . . . . . . . . 29

Spot-rump . . . . . . . 64

Stilt, Black-necked . . . . . . . . . 58

Swan, Trumpeter. . . . .43

Whistling . . . . . . . . . 43

Tatler, Wandering $. \quad . \quad . \quad . \quad . \quad . \quad . \quad . \quad .79$

Tattler. . . . . . . . . 75

Teal, Blue-winged . . . . . . . . . 18 Cinnamon . . . . . .18 Green-winged . . . . . . 17

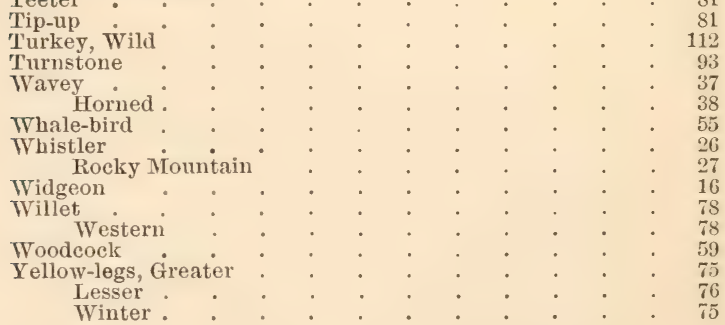







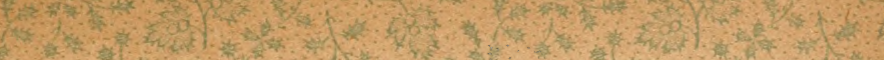

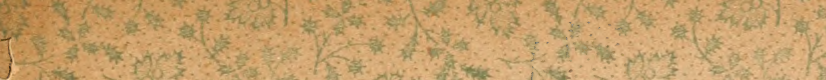 1.

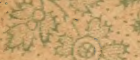
$(1+4)+x+3$
(x)
anting
(2) $n$

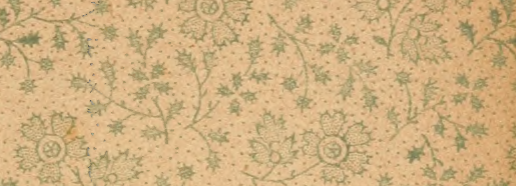 1.
(1)

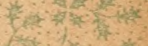
$x^{2}$
(ब)

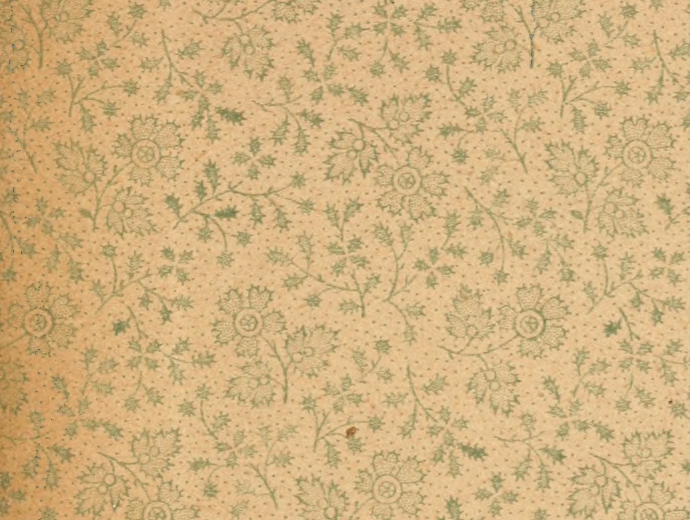

(1)

tef

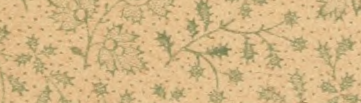

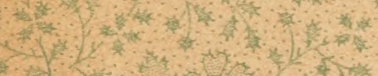

$$
\text { (ब) } 3 \text { तn }
$$

if

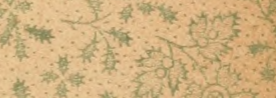

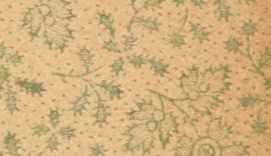

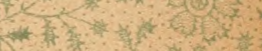
(3)

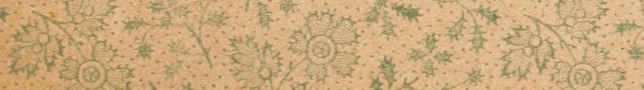

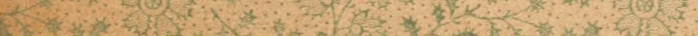






3. (5) 202 in
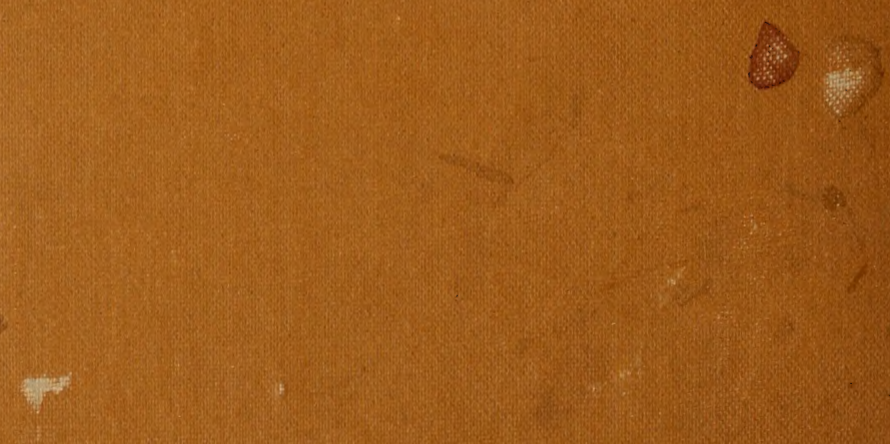

$x^{2}$

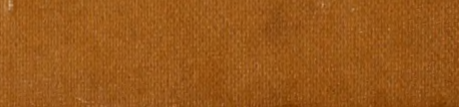

